\title{
Determinants of Internet Banking Adoption in Jordan
}

\author{
Haneen A. Abu-Assi ${ }^{1}$, Hani H. Al-Dmour ${ }^{1} \&$ Zu'bi M.F. Al-Zu'bi ${ }^{1}$ \\ ${ }^{1}$ School of Business, the University of Jordan, Jordan \\ Correspondence: Zu'bi M.F. Al-Zu'bi, School of Business, the University of Jordan, P.O. Box 13413 Amman, \\ 11942, Jordan. Tel: 962-7956-2939. E-mail: z.alzubi@ju.edu.jo
}

Received: July 28, 2014

doi:10.5539/ijbm.v9n12p169
Accepted: October 10, $2014 \quad$ Online Published: November 22, 2014

URL: http://dx.doi.org/10.5539/ijbm.v9n12p169

\begin{abstract}
The primary purpose of internet banking research is to investigate the factors that influence the E-Banking adoption of clients who have internet access. To develop a theoretical framework model in the context of this study, the literature that relates to the Technology Acceptance Model (TAM), Diffusion of Innovations (DOI), Technology Readiness Index (TRI) and their various adaptations were undertaken. Internet banking has been considered an innovative service, whose potential adoption by clients will be investigated. The model of this research purposes an extension to the latter models, which account for essential factors that affect the adoption of E-Banking services in Jordanian commercial banks.
\end{abstract}

The study population was identified as banking clients who regularly use their online banking system account. The study used the questionnaire survey method in order to test the hypotheses and to explore its implications. 350 questionnaires were disseminated to the research sample. Multiple Regression and One Way ANOVA tests were applied to test the research hypothesis.

The results show that compatibility, perceived ease of use, security and perceived usefulness positively affect internet banking adoption. Furthermore, this research adds a new component by studying the effect of all the independent factors together and identifies a positive relationship between them and internet banking adoption. Hence, synergistic relations between these factors should be secured in order to ensure their higher effect on internet banking adoption. In addition, the research demonstrates that all demographic categories studied have influenced internet banking adoption, indicating that they should be used to build the correct segmentation for consumers in order to develop proper marketing strategies.

Based on the findings of the research, a number of recommendations are presented to increase internet banking adoption among the Jordanian consumers. First, to enhance internet banking adoption, banks should combine the concepts of compatibility, perceived ease of use, perceived usefulness, and security into the online banking services concept in the stage of market planning and ensure proper synergy between these variables in order to increase the level of internet banking adoption. Moreover, both marketers and banks can utilize the demographic variables in order to improve their marketing activities for online banking. Finally, since the Jordanian financial system is going through a period of extensive change, the development process should not be linked to one specific bank or another, but instead all banks under the Central Bank of Jordan should try to build long-term strategies that include an awareness component in order to raise internet banking adoption awareness amongst Jordanian banking clients.

Keywords: internet banking, consumer behavior, Jordan

\section{Introduction}

Evolving consumers' requirements and continuing competitive pressures have required banks to develop new technologies and novel marketing tools. Since Internet banking is a product of this innovation, it has revolutionized the banking industry all over the world. Internet banking is about using the internet to deliver banking services to customers (Chi et al., 2007). Internet banking has become a common channel for providing banking services to customers due to its benefits to consumers and banks alike. One of these benefits is convenience, as banking transactions and other related activities can be performed in the comfort of customers' homes or offices.

The usefulness of conducting banking transactions at home or from the office eliminates the difficulties that are associated with driving to the bank, the cost of petrol, and parking. Internet banking also allows customers to 
perform banking transactions 24 hours a day, 7 days a week, 365 days a year. Despite the fact that internet-based electronic banking is one of the latest and most promising delivery channels for retail banking services, it is the least researched.

Currently, The Jordanian financial system is going through a period of significant change, the impact of which is transforming the way financial services are provided. These changes include, among others, a substantial increase in the number of alternative channels available for the delivery of services. The latest delivery channel introduced for financial services is internet or online banking.

Recently, It has been recognized that understanding the reasons behind accepting or rejecting computer systems such as internet banking is one of the most challenging issues in information system research, especially in Jordan. However, there are few empirical studies related to the adoption of internet banking service in Jordan (Al Sukkar \& Hasan, 2005; Al-Qeisi, 2009). Based on this gap it is important to have more empirical studies on antecedents of internet banking service adoption, since past studies have included only a few variables. Therefore, this study intends to investigate some specific behavioral and cultural factors of internet banking service adoption/non-adoption.

\subsection{Research Problem}

Traditional branch-based retail banking maintains its popularity and remains the most used method for conducting banking transactions in Jordan and in any other country.

However, internet technology is rapidly shifting the way banks design and deliver personal financial services. Currently, commercial banks in Jordan are looking to improve their operations and reduce their costs through internet-based E-banking systems. In spite of their availability, these systems remain somehow unnoticed by the customers, and certainly are underused. Therefore, it is important to understand users' acceptance of internet banking, and to identify the reasons behind their adoption of internet banking. The answer to these issues is crucial since they will help the banking industry formulate their marketing strategies to promote the latest forms of internet banking systems.

In the light of those findings, the research problem would be: "What are the factors affecting internet banking adoption among Jordanian clients?"

\subsection{Research Importance}

Since internet banking services are beneficial for both the banks and their customers, banks have begun using the internet as one of their distribution channels (Karjaluoto, 2002). It is a customer friendly method; customers can carry out their bank transactions or contact their banks faster and without any limitations of time and place. Electronic service is becoming a viable option for communication between financial service providers and their customers, therefore many organizations in the financial services industry are taking advantage of internet capabilities and implementing them quickly (Rotchanakitumnuai \& Speece, 2004).

Undoubtedly, in order to enhance consumer internet banking adoption, the Jordanian financial institutions, especially banks, must make key improvements that deal with consumer concerns and understand the key factors that influence consumer internet banking adoption.

Therefore, this study aims to determine the factors that often affect internet banking adoption by Jordanian consumers.

In other words, internet banking acceptance will be studied using the factors that are important to success, defined as consumers who are using internet banking directly. Hence, more knowledge on the factors that affect internet banking adoption is needed in order to better understand and facilitate the adoption.

\subsection{Research Objective}

In the light of what has been discussed in previous sections, this study will try to answer the questions that have been raised in the aforementioned problem definition, and to achieve the following objectives:

- To examine the key determinants of internet banking adoption behaviour in Jordan.

- To integrate the technology acceptance model (TAM), technology readiness index (TRI) and the diffusion of innovations (DOI) to develop predictions of internet banking adoption.

- To find out whether the respondents' demographic characteristics (age, gender, education and income) have an influence on internet banking adoption. 


\subsection{Research Limitations Hypothesis}

This study has several limitations. Firstly, the scarcity of previous local studies and statistics regarding internet banking adoption in Jordan. Second, this study defined five factors in considering consumers' acceptance and adoption of internet banking. However, there may be additional factors that can influence the internet banking adoption but are not tested. Further empirical research is essential to define and test other factors that can influence customers' adoption of internet banking services, such as type of internet connection used, self-efficiency and culture. The third limitation concerns the sample. The sample was taken from clients who are officially registered in the $\mathrm{ABC}$ bank online banking system. These limitations facilitate the way to future studies. Furthermore, the technique used to collect data from the interviewers raises the question of whether they were able and willing to express their actual preferences since individuals may be biased toward verbally expressing their attitudes.

\section{Theoretical Foundation}

The major goal of this section is to provide a theoretical analysis regarding internet banking adoption. Previous studies that have tried to identify the main variables affecting internet banking adoption are thoroughly reviewed.

\subsection{Adoption}

According to Rogers and Shoemaker (1971), consumers pass through "a process of knowledge, persuasion, decision and confirmation" before they are ready to adopt a product or service.

So the stages through which a technological innovation passes are:

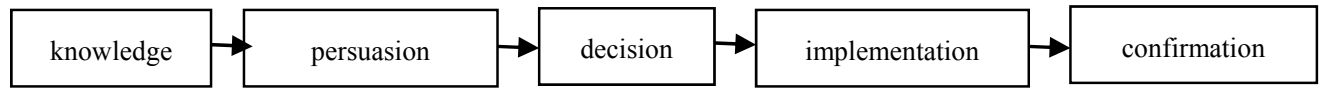

Figure 1. Stages of technological innovation

A prospective adopter goes through certain stages before making a decision on whether to accept (adopt) or reject an innovation. Many researchers have focused on the adoption process, Rogers has been one of them, he defined it as the "the process through which an individual or other decision making unit passes from first knowledge of an innovation, to forming an attitude toward the innovation, to a decision or rejection, to implementation of the new idea, and to confirmation of this decision" (Rogers, 1983, p. 20).

The period for adopting an innovation can be short or lengthy.

Therefore adoption can be briefly define as the acceptance and continued use of a product, service or idea.

\subsection{Internet Banking}

Despite that banks offer different levels of services, there is lack of studies that deal with these services and the used channels. Sciglimpaglia and Ely (2002) stated that offering banking services via the net is very risky and might lead to losing customers. They reported that 32.9 percent of all customers would be tempted to switch banks if they discovered a better rate, and this percentage would increase to 40.5 percent if customers have an existing internet connection. Such results stress the importance of understanding and addressing customers' needs and wants. According to Chung and Paynter (2002), there are four factors that affect customer satisfaction in internet banking (security, download time, response time, and transactions free of technical problems).

Chung and Paynter concluded that factors that are important to customers' adoption of internet banking include age, education, being an existing phone customer, and perceiving the service as not being complicated.

\subsection{Internet Banking in the Middle East and Jordan}

The early adoption of internet banking in Jordan emerged in 2000 with two local banks: Arab bank and Jordan Kuwait Bank (Siam, 2006). During the period of 2001- 2003 compared to developed international markets such as the US, the banks in Jordan did not fully utilize the concept of web banking. The lack of top management support and security are the reasons behind the lag in the banking sector in Oman (a survey aimed at IS executive and managers). Other less significant factors were power conflict in the internet banking adoption decision and the general lack of investment in e-commerce applications.

During this era as surveyed by Awamleh et al. (2003), the website was used only as an informative tool; it provided customers with different types of information such as promotional information, institutional information (contact details, branch locations, details about board of directors) and information about special 
events. Only two banks in Jordan offered limited number of services through the web, only a few banks made their transactions online and none of the Jordanian banks provided their customer either with an online banking account or online investment application.

Recently, in order to achieve a competitive advantage and increase the responsiveness to customers' needs with lower cost, many banks in Jordan have decided to adopt internet banking (Siam, 2006). In addition to that, they have begun implementing more advanced technologies to push more costs in front of the customers (Arab Advisor, 2007).

The late adoption of internet banking amongst banks in Jordan did not affect their competitive position in the Middle East and in Africa (Trajhova, 2005). For example, Jordan Kuwait Bank is one of the best banks in providing internet banking and bill payment in the Middle East and Africa. Moreover, in 2007, Standard and Chartered in Jordan was the best in corporate and institutional internet banking (Keeler, 2007).

\subsection{Research Theoretical Background}

Seminal methods for measuring technology acceptance, the readiness to use it and the diffusion of innovation, provide us a better understanding of the reasons behind consumers' usage of internet banking. This helps us in developing a framework for this study. In this section we begin by briefly describing three frameworks: the pioneering diffusion literature of Rogers (1983) and Ostlund (1974), the Technology Readiness Index (TRI) of Parasuraman (2000), and the Technology Acceptance Model (TAM) of Davis (1989).

\subsubsection{The Diffusion of Innovations (DOI) Perspective}

Rodgers introduced the Diffusion of innovation perspective in 1983, when he looked for the determinants of information system usage and adoption. These factors were: information sources and communication, innovation characteristics and individual adopter characteristics. According to the theory of Diffusion of Innovation (DOI), adopters assess the innovation based on different features such as complexity (ease of use), relative advantage, trial ability, compatibility and observability. All of these features (attributes) were positively related to the rate of adoption except that the perceived complexity of innovation was negatively related (Rogers, 1995). Since then this theory has been supported by different empirical studies for example, Kolodinsky et al., (2004); Howcroft, (2001); Black et al., (2001); Howcroft, Hamilton, \& Hewer, (2002); Alagheband (2006).

Rogers (1983) identified these factors and defined them as follows: complexity is defined as the degree of perceived difficulty of use and understanding of innovation. The second factor is relative advantage, defined as the extent to which an innovation is perceived as being better than the idea it replaced. The third one is the trialability, defined as the degree to which innovation can be tested. The fourth reason is compatibility, which is the consistency of innovation with current adopters' needs, values, and past experiences. The final factor is observability which is the degree of visibility or in other words the extent to which innovation's results are visible to others.

\subsubsection{Technology Readiness Index}

The Technology readiness index is a framework that is generally related to technology. Since people have different traits, their beliefs about aspects of technology also differ. The relative strength of each trait reflects the individual's openness and acceptance of technology. Therefore TRI indicates a person's belief regarding technology not as an indicator of his or her competency.

The TRI of Parasuraman (2000) contains four factors: optimism, innovation, discomfort, and insecurity. Optimism is the degree to which people believe that technology increases control, flexibility and efficiency in their lives; in other word it is the positive view of technology. Innovation was defined as the extent to which people are creators and thought leaders, while discomfort was defined as the feeling of being overwhelmed with technology and a lack of control over it. The final factor is insecurity, the skeptical view of technology, in other words, being distrustful of technology and its ability to work in a proper way.

Optimism and innovation are identified as enablers of the readiness of technology, on the other hand, discomfort and insecurity are inhibitors (Parasuraman, 2000). Therefore, if consumers are not "ready" to be internet banking users, they are likely to express discomfort and insecurity about the service and feel less optimistic and innovative about the technology.

\subsubsection{The Technology Acceptance Model (TAM)}

Based on the Theory of Reasoned Action (TRA), David explains computer usage behavior by developing the technology acceptance model (TAM).

According to the TAM, one's attitude and intention towards using technology or a system depends on the 
perceived usefulness (PU) and the perceived ease of use (PEOU) (Davis, 1989; Davis et al., 1989; Mathieson, 1991). TAM bears comparison to TRA (Taylor \& Todd, 1995); it has higher convergent and discriminant validity (Adams et al., 1992). Convergent and discriminant validity reported was high allowing to integrate other factors to the framework to gain a better explanation of the users' intention for adoption (Hong et al, 2006). According to McKechnie et al., (2006) TAM is beneficial in understanding the factors that affect the degree of internet usage in financial services. When customers (users) perceive that through new information technology they can finish their work efficiently, their perception of product's usefulness will be greater. In other words, as the perceived product usefulness increases, the product's adoption increases. Similarly, when customers (users) perceive a product as an easy to use product, the probability of having a positive attitude toward adopting that product is higher. Based on this, the perceived usefulness and the perceived ease of use are assumed to be two external variables that affect the user's acceptance of information technology tools. Also the perceived ease of use will affect the perceived usefulness (Davis, 1986 \&1989; Henderson \& Divett, 2003; Davis, 1986 \& 1989; Hsiao \& Hung, 2004). Moreover, the perceived usefulness and the user's attitude have a positive relationship with user's behavioral intentions and acceptance.

Regardless of the popular use of TAM, it has been criticized by many researchers. First, it cannot be used and applied to users who are obligated to use technology, despite the fact that they represent a large percentage of users. Second, it did not take into consideration the surrounding environment, situational influences and other external factors, particularly culture (McCoy et al., 2007; Al-Sukkar \& Hasan, 2005). Third, it can easily lead to misinterpretation of the actual processes of continuous use (Kim \& Malhotra, 2005). There is no research that has studied TAM in depth in terms of perceived usefulness and ease of use, in conceptualizing the model's variables and adding new variables that explain their effects (Bagozzi, 2007).

All of these theories look at the importance of consumer's perception as a determinant of behavioral intentions. Taking all of these three theories together creates a synergy, in other words, it is better to take them all together than take each one separately.

\subsection{Independent Variables}

\subsubsection{Perceived Ease of Use}

Davis (1989) defined "perceived ease of use as the degree to which a person believes that using a particular system would be free of effort" (Davis, 1989, p. 320).

To ensure that the customer will accept and take-up the technological innovation, it must be easy to use (Wallis Report, 1997). The degree of difficulty of use and understanding was one of the important reasons for home banking failure in the USA (Dover, 1988). As emphasized by Rogers' (1983) analysis of diffusion, individual's understanding and perception of a new technology is very important as a shaper of their acceptance. Scarbrough and Corbett (1992) support this and found that "understandings of consumers" is an essential component in the diffusion of innovation in the context of internet banking. Also Mathieson (1991) supported the theory that there is a relationship between the perception of ease of use and the perceived minimum effort required. That is, if customers perceive internet banking as being easy to use and not technologically complicated, there is a greater likelihood of adoption. This idea is supported by Chong, et al., (2010, p. 272), "Given that users do not have face to-face interaction in an internet environment, user friendliness and the ease of use of the web sites will lessen the threat to use internet banking by the customers." Many of the researches supported that there is a positive and upward relationship between the perceived ease of use and the probability of adoption of internet banking (Wang, et al., 2003; Hernandez \& Mazzon, 2007; Gounaris \& Koritos, 2008). On the other hand, other researches (Pikkarainen et al., 2004; Eriksson et al., 2005) contradicted this result and concluded that the ease of use has no influence on the internet adoption.

\subsubsection{Usefulness}

Usefulness is defined as "the degree to which a person believes that a particular information technology would enhance his or her job performance." It has also been shown to be a contributing factor towards internet adoption (Leaderer et al., 1999, p. 17).

Based on that definition, it can be said that, the superiority of internet banking over the regular banking methods can affect the percentage of internet banking adoption. For instance, the flexibility of bank transactions in terms of doing it any time and at any location with internet access, would be an advantage to people who are extremely busy and have tight schedule (Rudi Hoppe et al., 2001).

Moreover (Chi et al., 2007), showed that the perceived usefulness has a potential effect on adoption and the behavioral intention, while Lederer et al. (2000) found that perceived usefulness and ease of use are two 
important factors for internet banking adoption.

\subsubsection{Compatibility}

Compatibility is another important dimension of the innovation diffusion theory. It refers to the fact that there is a high probability for innovation to be adopted by an individual, when it is consistent with his or her job's responsibility and value system (Tornatzky \& Klein, 1982; Agarwal \& Prasad, 1998). Therefore, the more an individual uses the internet and the more he or she perceives the internet as compatible with his or her lifestyle, the more likely that individual will adopt internet banking (Hoppe et al., 2001).

Internet banking has been considered a delivery channel that fits with the modern banking customers who are computer literate and familiar with the internet. The innovation should be compatible with the individual's and group's values or beliefs.

Given the larger numbers of US customers shopping/trading online, internet banking services are quite compatible once customers overcome the security and privacy concerns.

\subsubsection{Trialability}

Trialability is the degree to which an innovation can be tested. According to Rogers customers who can test and experiment with an innovation are more likely to adopt it, since they will be more comfortable with it (Rogers, 1983). Moore and Benbasat (1991) concluded that trainability positively affects the attitude toward internet banking. Put differently, if customers get a chance to test-drive the technology, a positive attitude toward internet banking can be built. Therefore, in order to promote acceptance, banks should offer their potential customers with gradual (step-by-step) demonstrations which illustrate the steps for using internet banking on the bank website (Moore \& Benbasat, 1991).

Agarwal and Prasad (1998) also support this. They state that the likelihood of adopting new technology will increase as customers (potential adopters) feel comfortable toward it after experimentation.

According to Tan and Teo (2000), testing the innovation can provide customers with a predictable situation, by diminish the unknown fears and providing them with a solution for probable mistakes. Internet banking is a free service; the cost and the risk of trial are low. When customers are offered a low risk and low cost service, innovation will diffuse rapidly.

\subsubsection{Security}

Another vital factor that is taken into consideration by customers before adopting an innovation is the involved risk. Security has been identified as an influential factor for customers' acceptance (Daniel, 1999). In the context of internet banking, security refers to transactions' security and reliability via the internet. Unless customers perceive it as secure and safe, they won't adopt it (Milind Sathye, 1999). One of the major barriers of internet banking adoption is the security risk. It is an important determinant of innovation adoption from the customers' perspective (Cooper, 1997). According to O'Connell (1996), "security concerns" are considered an important cause for the slow-moving growth of Australian internet banking. The report in 1997 stated that banks' clients will use the internet to carry out their financial transactions, if security is enhanced. Also Rothwell and Gardiner (1984) supported this; they developed a framework for the needs of users in technological innovation, and they identified the "safety of use" as an influential factor for potential users. In accordance with Stewart (1999), the lack of customers' trust in the web merchants and the electronic channels lead to the failure of the retail distribution channel via internet. As confirmed by Sathye (1999) security is a very strong and an important concern of internet financial transaction. Thus, as customers perceive the use of internet banking as low, they would adopt it.

\subsection{The Demographic Variables}

Generally, personal, and socio-demographic characteristics have been used to profile adopters. Age, gender, household income, and education, are the most popular used identifiers for adopters. In internet banking specifically, Mattilia et al. (2003) found that the client's income and education predicted whether or not he or she will adopt internet banking, and Sathye (1999) pointed out that the likelihood to adopt internet banking is high for young, educated, and wealthy consumers.

\subsubsection{Gender}

Some studies stated that the gender of the clients have an effect on their behavior. Fink (2005) indicated that males are adopting internet banking online systems at a higher rate than women. Some researchers have demonstrated that liberal women with higher education and income levels display a higher internet banking adoption (Baraghani, 2008). 


\subsubsection{Age}

The influence of age on internet banking adoption has been an argumentative point with many researchers in the literature. Some researches support a significant correlation between age and internet banking adoption (Fink, 2005). In addition, according to a study conducted by Wungwanitchakorn (2002), young people are more likely to be adopters of internet banking online systems than elderly people. Eriksson (2004) stated that young people are more willing than older generations to adopt internet banking.

\subsubsection{Education Level}

Some studies argued that there is a direct correlation between a client's education level and the adoption of internet banking (Eriksson, 2004).

Because educated customers have high awareness of new technologies, they are assumed to adopt internet banking online system. Also Baraghani (2008) found a positive correlation between education and internet banking adoption while others argued that there is no such correlation (Fink, 2005).

\subsubsection{Income Level}

Individuals with higher income were found to adopt internet banking online systems (Wungwanitchakorn, 2002). In general, income level will have an influence on internet banking adoption since the clients with higher level income will be the ones interested in using the internet banking online systems (Black et al, 2001). A recent study conducted by Fink (2005) showed that consumers with higher income also show higher levels of internet banking adoption.

\section{Research Methods}

The previous Section provided an in-depth review of internet banking adoption and the variables affecting it according to previous literature. In this Section, the research methodology will be clarified. The methodology includes the theoretical framework, research type and scale, and research population, as well as data collection and analysis procedure. The validity and reliability of the study are also examined.

\subsection{Research Theoretical Frame Work}

Despite the differences between the TRI, TAM and Diffusion Models in terms of the investigative drive, there are still some common themes. Table I shows the degree of commonality between the distinct studies. In illustrating these themes, it is noticed that different researchers use different labels for their developed factors. Therefore different labels refer to the same factors. Table I illustrates the different factors defining the TRI, TAM and diffusion models.

Table 1. A comparison of the TRI, TAM and diffusion models

\begin{tabular}{lll}
\hline \multicolumn{2}{l}{ TRI (Parasuraman, 2000) TAM (Davis, 1986) External Factors Diffusion (Rogers, 1962) } \\
\hline Discomfort & Ease of use & Complexity \\
Optimism & Usefulness & Relative advantage \\
Innovativeness & NA & Innovativeness \\
NA & NA & Compatibility \\
NA & NA & Trialability \\
NA & NA & Observability \\
Security & NA & NA \\
\hline
\end{tabular}

Note. NA: Not Available.

Regarding Trialability, it is not applicable to be tested and be experienced before the decision of adoption or not adoption have been done by the customer. On the other hand, not offering a trial opportunity may hinder internet banking adoption, that's why this variable will not be tested and has been removed from the model (Athanasioset et al., 2011).

Innovativeness is a variable that can be studied on an organizational level, and since this research is conducted on a customer level, we will exclude this variable.

The identified and perceived attributes of this empirical work and the above theoretical frameworks were considered as the primary list of constructs. The purpose was to examine the relevance of the influencing factors 
in an inclusive set. This approach was compatible with the purpose of this study to examine Jordanian clients' internet banking adoption. Many of the dimensions in the theoretical frameworks as observed were overlap.

Because Rogers' dimensions are broadly defined, many of the researchers' constructs are similar to each other, for example, Davis took usefulness and ease of use similar to perceived relative advantage and perceived complexity of Rogers, to Parasuraman's constructs of optimism and discomfort respectively.

Based on the existing empirical work, many of the constructs' aspects were operationalized (Churchill, 1979). The purpose was to check that all of the items that represent each of the relevant factors have content validity and not overlap with the other construct categories.

\subsection{Theoretical Framework}

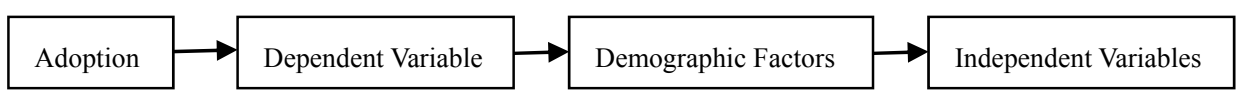

Figure 2. Research theoretical framework

\subsection{Operational Definition}

The current study relied on different scales in order to measure the main variables. The scales used to measure the research constructs were built on previous literature.

Perceived ease of use: the extent to which the potential user expects the potential system to be free of effort (Davis, 1989). The scope of what actually constitutes recognized ease of use has been discussed within the literature. According to Zeithami et al. (2002), the ability to understand or apply innovation can be associated with perceived ease of use.

Questions 9-15 in the questionnaire were used to measure perceived ease of use. Perceived Usefulness: Davis et al., (1989) defined perceived usefulness as the individual's perception of the benefits of the new technology in terms of improving and enhancing performance. In a similar vein, this construct is defined by Venkatesh et al. (2003) as the extent to which a person values new technology to improve his or her job performance.

Questions 16-18 in the questionnaire were used to measure perceived usefulness. Compatibility: the extent to which the innovation matches with the values, current needs and previous experience of the prospective adopter (Rogers, 1983).

Tornatzkey and Klein (1982) find that there is a positive relationship between compatibility and innovation adoption. In other word, when the innovation is compatible with job responsibilities and value system.

Questions 19-21 in the questionnaire were used to measure compatibility.

Trialability: Rogers (1983) defined it as the extent to which an innovation can be tested on a limited bases before deciding to adopt it. He argued that customers can overcome doubts and fear if they test internet banking application on a limited basis.

Questions 22-24 in the questionnaire were used to measure trialability.

Table 2. Independent variables source scale

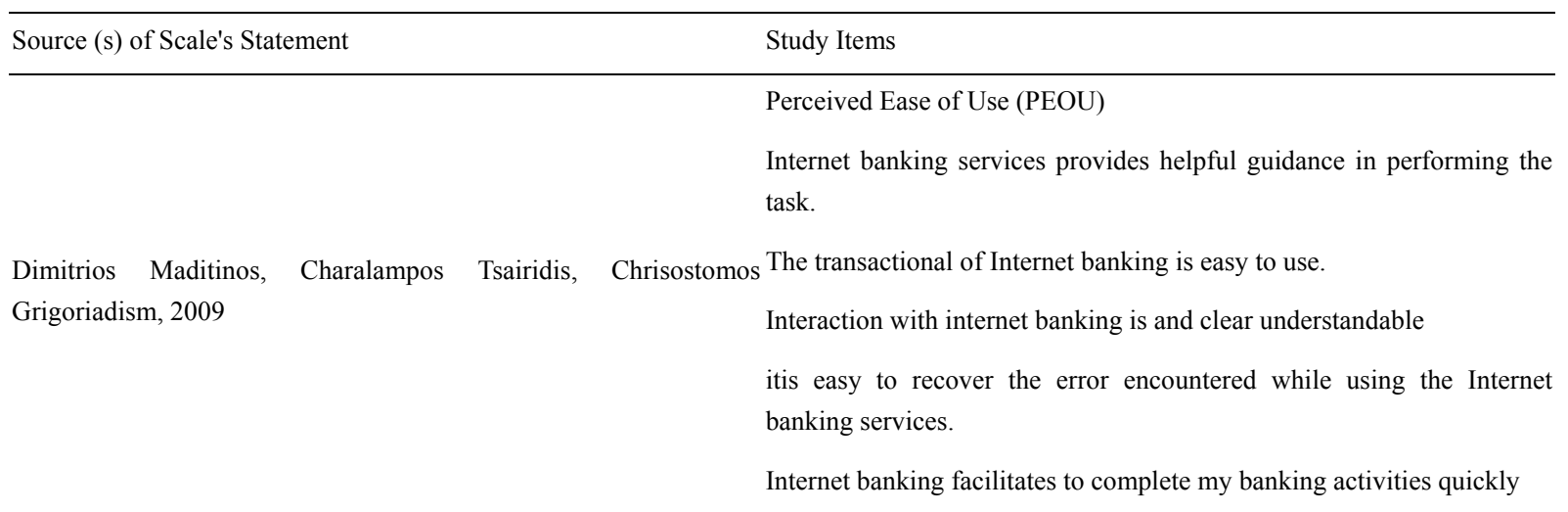


Internet banking allows to manage my finance efficiently.

Internet banking helps to increase customers' productivity

Perceived Usefulness

Dimitrios Maditinos, Charalampos Tsairidis, Chrisostomos

Grigoriadism, 2009

Use of internet banking services can save customers time

Internet banking facilitates to complete my banking activities quickly

Using Internet Banking for doing banking transactions much easier.

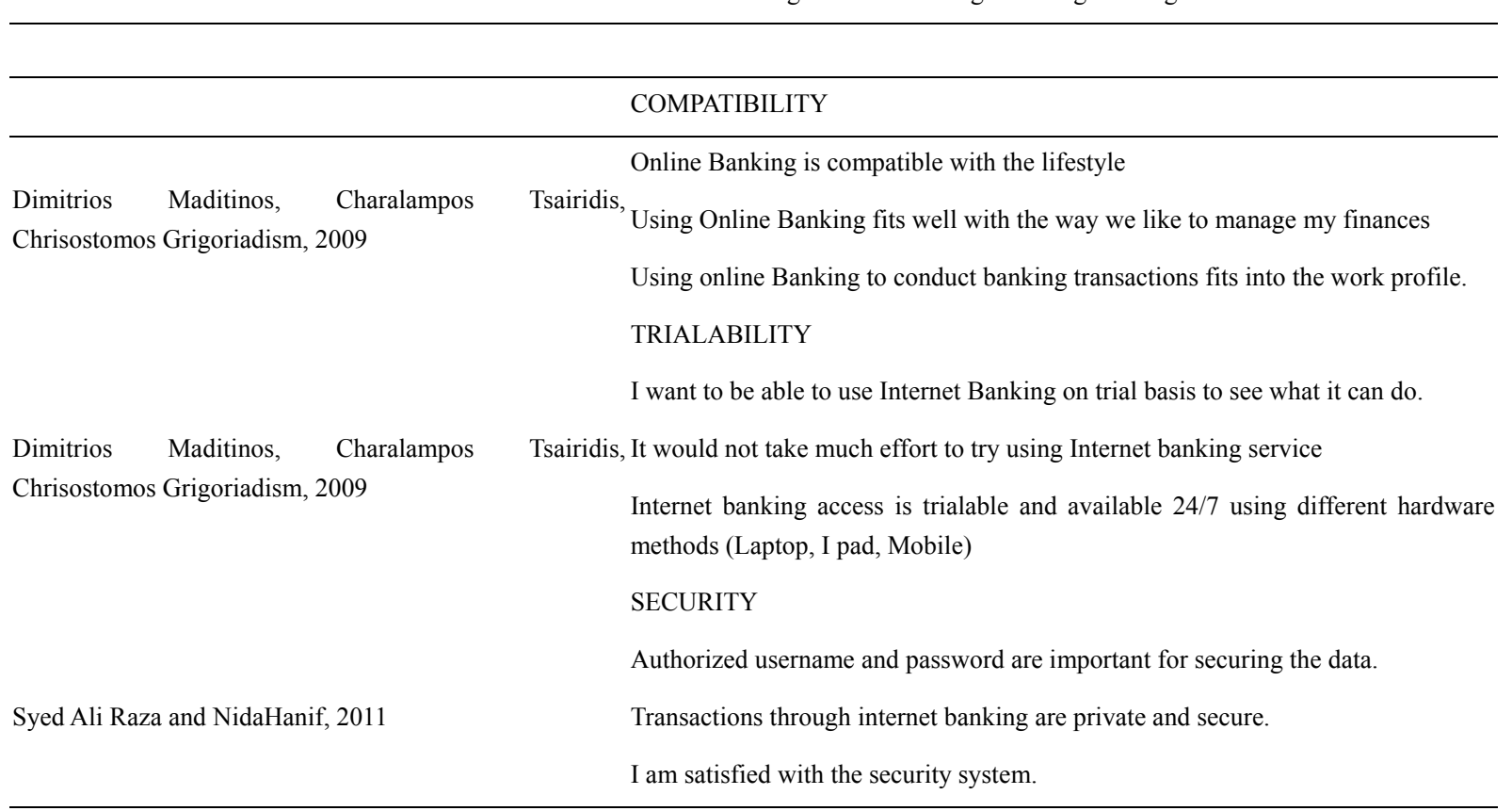

Note. **Some questions were modified to match the current study context.

Table 3. Independent variables source scale

\begin{tabular}{ll}
\hline Source (s) of Scale's Statement & Study Items \\
\hline Internet Banking Adoption \\
I am highly convinced in using internet banking. \\
I am willing to use internet banking services more frequently \\
Syed Ali Raza and NidaHanif, 2011 will highly recommend my friends to adopt online \\
banking.
\end{tabular}

Note. **Some questions were modified to match the current study context.

\subsection{Research Hypotheses}

The research aimed to test the following three null hypotheses and sub hypotheses:

H01-There is no significant relationship between the independent variables (perceived ease of use, compatibility, Perceived usefulness, trialability, security) taken together and internet banking adoption.

H02-There is no significant relationship between the independent variables (perceived usefulness, perceived ease of use, compatibility, trialability, and security) taken separately and internet banking adoption.

H02.1: There is no significant relationship between perceived usefulness and internet banking adoption.

H02.2:There is no significant relationship between perceived ease of use and internet banking adoption.

H02.3: There is no significant relationship between compatibility and internet banking adoption.

H02.4:There is no significant relationship between trialability and internet banking adoption.

H02.5:There is no significant relationship between security and internet banking adoption. 
H03 - There is no difference in internet banking adoption due to "the clients characteristics such as: "gender, age, educational level and income level" taken separately.

\subsection{Research Type and Scale}

The study proposed to test the relationship between internet banking adoption and five variables: trialability perceived usefulness, compatibility, perceived ease of use, and security. Hence, it is a relational and correlational study because it searches for the existence of relationships between the independent and the dependent variables. In addition, it is considered quantitative research, as it will produce quantitative data, and is concerned with hypothesis testing.

The study used the questionnaire survey to verify the hypotheses and research framework. The questionnaires were distributed in different bank branches in Amman and contained 27 questions. They also contained questions regarding the key characteristics of respondents, namely: age, income, gender, and education. Also, the study tried to measure the frequency and time spent by the client on internet banking adoption.

The study used a five-point Likert scale from 1 to 5 , rating from strong disagreement to strong agreement, to measure the questionnaire items. It has become quite common to use the five-point Likert scale measure in many studies (Chen et al., 2006).

\subsection{Research Population and Sample Size}

Population refers to the entire group of people, events, or things of interest that the researcher wishes to investigate (Sekaran, 2008). The population for this study was all the electronic banking service clients of Arab banking corporation in all Jordanian cities. A sample of (370) clients constitutes the sample of this study, based on (27) Branches of $\mathrm{ABC}$ Bank in Jordan. The official registered list for the electronic banking users was considered the sampling frame.

Sampling has been described by Collis and Hussey (2003) as a "positive methodology whereby a sample of subjects is drawn from a population and studied to make inferences about the population." Based on the previous definition, this study will mainly relay on using the survey method, which is a quantitative research tool used by the majority of social science scholars. Thus, the self-administered method (drop-off) is a data collection method in which the researcher delivered the questionnaires within each branch and returned back to collect them. Since there is no direct contact between the researcher and the respondents, the interview bias is minimized (Hair et al., 2003).

\subsection{Study Horizon}

The horizon selected for this study was from January 2013 until August 2013. The study is considered cross-sectional as the data was gathered just once during the time horizon of the study.

\subsection{Sources of Data}

The research data was collected from two sources:

1)-The secondary data was obtained from sources which were related to the research subject such as books, periodicals, government publications and specialized web sites, as well as through an examination of previous studies related to the same subject. With this research type, it is important that the researcher has a clear vision of the situation being investigated before carrying out the procedures to collect the primary data.

2)-The primary data was obtained through designing and distributing the questionnaires to measure the study variables.

\subsection{Data Collection Instrument}

The research instrument used in the study was the questionnaire, which was structured based on prior research and the literature review. Most of the questions in the questionnaire were taken from the study conducted by Dimitrios Maditinos, Charalampos Tsairidis, and Chrisostomos Grigoriadism (2009) and Syed Ali Raza and Nida Hanif (2011) yet the researcher modified the questions to be consistent with the research objective and intended respondents and added some questions to address the added variables

The questionnaire has been developed through several stages:

- Review of previous research and study variables in order to determine the independent and dependent variables.

- Distribution to experts and scholars who were asked to modify the questionnaire. 
- Distribution to a sample of seven respondents as a small-pilot study to test their understanding; afterwards some questions were modified to make the language understandable.

- Distribution to a second pilot study was performed on the first 50 questionnaires that were filled by some respondents using the SPSS (version 20) program. The analysis illustrated that the questionnaire had a high reliability.

\subsection{Components of Questionnaire}

The questionnaire was accompanied with a letter to describe the purpose behind conducting the survey and to make the questionnaire appealing to the respondents. In addition, the importance of friendly cooperation of the respondents in filling out the questionnaire was explained to help increase the response rate.

Following the cover letter, the questionnaire was divided into two major parts:

(1) The first part covered the demographic variables of the respondents which are: age, education level, gender, monthly income, and frequency of using internet banking (Questions 1 to 5).

(2) The second part covered the independent and the dependent variables of the study and consisted of 22 questions.

Questions 6 to 8: Internet banking adoption
Questions 9 to 15: Perceived ease of use
Questions 16 to 18: Perceived usefulness
Questions 19 to 21: Compatibility
Questions 22 to 24:Trialability
Questions 25 to 27: Security
Note. ${ }^{* *}$ The questionnaire of this study is attached in the appendix.

\subsection{Rate of Return}

A total of 370 questionnaires were returned and only 350 were usable. The other 20 questionnaires were unusable because the respondents had left a few questions unanswered. The response rate of the survey was $95 \%$, which was $350 / 370$ respondents.

\subsection{Data Analysis Techniques}

After gathering all the completed questionnaires from the respondents, and before the data analysis, the data was coded in order to transform the research information from the questionnaires into computer files so that computers could analyze the data. The researcher used the SPSS (Version 20) program in order to analyze the data.

Various descriptive and inferential statistical methods have been used to analyze the data, such as:

Cronbach's Alpha Reliability measure

Descriptive statistics such as:

- Frequency Distribution Tables, Mean, And Standard Deviation;

- Multiple regression analysis;

- Analysis of variance (Anova);

- One way analysis of variance;

- Tukey's post hock test.

\subsection{Validity and Reliability of Scales}

\subsubsection{Validity of Scales}

Validity means that the findings are exactly what they should be (Saunders et al., 2000); it is defined as the ability of the used instrument to measure the particular variable that it is supposed to measure (Sekaran \& Bougie, 2010).

In order to check the appropriateness of the questionnaire's questions to the study's main objective, and to examine validity of the research instrument, the questionnaire has been presented to a group of specialized people and experts in related subjects. They proposed some adjustments and suggested some necessary correction to ensure improvement of the validity of the instruments. The questionnaire was subsequently 
amended in accordance with their instructions and recommendations. Approval of the majority of the experts was considered indicative of the questionnaire's validity.

In addition the researcher conducted a pilot study by meeting 7 people from the research sample. These seven people use online banking for their daily transactions. The researcher disseminated the research questionnaire in advance and then met with those individuals to discuss all its items, and asked them to give their feedback after filling out the questionnaires to identify unnecessary, difficult or ambiguous questions. The pilot study was followed by some revisions, before it was distributed to respondents.

\subsubsection{Reliability of Scales}

Reliability of an instrument is testing for both consistency and stability. Consistency indicates how well the items measuring a concept hang together as a set (Sekaran \& Bougie, 2010). The role of reliability is to reduce the errors and biases in a study (Yin, 1994). Also according to Chisnall (1997), reliability is concerned with consistency, accuracy and predictability of specific research findings.

Cronbach's alpha is a reliability coefficient that indicates how well the items in a set are positively correlated to one another. The closer Cronbach's alpha is to 1, the higher the internal consistency reliability and the greater the reliability of the instrument according to Sekaran and Bougie (2010). The researcher used Cronbach's alpha in order to measure the reliability of the information and results obtained through the questionnaire. Sekaran and Bougie (2010) stated that reliabilities that are less than 0.60 are considered poor, those in the 0.70 range are acceptable, and those more than 0.80 are excellent. This is the scale that the researcher relied upon to determine the reliability of the factors.

Table 4 showed the results of Cronbach's alpha to measure the internal consistency reliability for measuring the independent variables of the study, while Table 5 showed the results of Cronbach's alpha for the dependent variable.

Table 4. Cronbach's alpha/ the independent variables

\begin{tabular}{lcc}
\hline \multicolumn{2}{l}{ Independent Variables Cronbach's Alpha No. Of Items } \\
\hline Perceived ease of use & .8 & 7 \\
Perceived usefulness & .7 & 3 \\
Compatibility & .7 & 3 \\
Trialability & .7 & 3 \\
Security & .7 & 3 \\
\hline
\end{tabular}

Table 4 represents the measurement of Cronbach's Alpha for the independent variables as follows:

- Perceived ease of use has been measured though 7 questions and Cronbach's Alpha was .8, which is excellent.

- Perceived usefulness has been measured by 3 questions and Cronbach's Alpha was approximately .7, which is acceptable.

- Compatibility has been measured though 3 questions and Cronbach's Alpha was .7, which is acceptable.

- Trialability has been measured though 3 questions and Cronbach's Alpha was .7, which is acceptable.

- Security has been measured though 3 questions and Cronbach's Alpha was .7, which is acceptable.

Table 5. Cronbach's alpha/the dependent variable

\begin{tabular}{lc}
\hline The Dependent Variable & Cronbach's Alpha No. Of Items \\
\hline Internet banking adoption .718 & 3 \\
\hline
\end{tabular}

Results in table 5 showed that the result of Cronbach's Alpha for the dependent variable was .718; this means that the reliability of the measurement instrument is acceptable.

\section{Data Analysis}

The main focus of this Section is on data analysis and results of the survey in order to study the effect of the 
independent variables upon internet banking adoption by using descriptive and inferential statistical methods. This Section aims to answer the research question, and to test the hypotheses.

\subsection{Descriptive Analysis}

This section is divided into two parts: the first one presents the frequency distribution and percentages applied to describe the data related to general characteristics of respondents such as gender, age, education level, monthly income level, and the frequency of using internet banking on the adoption of internet banking. The second part of the descriptive analysis investigates the variables of the study in order to answer the research question.

4.1.1 Characteristics of the Study Sample

1) Gender

Table 6. Frequency distribution, percentage of gender 42

\begin{tabular}{|c|c|c|c|c|}
\hline Gender & Frequency & yercent & Valid Percent & Cumulative Percent \\
\hline Male & 199 & 56.9 & 56.9 & 56.9 \\
\hline Female & e 151 & 43.1 & 43.1 & 100.0 \\
\hline Total & 350 & 100.0 & 100.0 & \\
\hline
\end{tabular}

Based on the findings in Table 4.1, the gender distribution of the respondents who participated in the study were 151 females (43.1\%) and 199 males (56.9\%).

2) Age

Table 7. Frequency distribution, percentage of age

\begin{tabular}{|c|c|c|c|c|c|}
\hline \multirow[t]{2}{*}{ Age } & & Frequency & Percent & \multicolumn{2}{|c|}{ t Valid Percent Cumulative Percent } \\
\hline & $18-24$ & 410 & 2.9 & 2.9 & 2.9 \\
\hline \multirow{3}{*}{ Valid } & $25-34$ & 4103 & 29.4 & 29.4 & 32.3 \\
\hline & $35-44$ & 4180 & 51.4 & 51.4 & 83.7 \\
\hline & $45-54$ & 49 & 14.0 & 14.0 & 97.7 \\
\hline & 5 & 8 & 2.3 & 2.3 & 100.0 \\
\hline & Total & 350 & 100.0 & 100.0 & \\
\hline
\end{tabular}

According to the age variable, the highest percentage of internet banking adopters are between 25 years and 44 years old, with the majority of people age 35 to 44 years old.

3) Education Level

Table 8. Frequency distribution, percentage of educational level

\begin{tabular}{lllll}
\hline Educational Level & \multicolumn{5}{c}{ Frequency Percent Valid Percent Cumulative Percent } \\
\hline High school & 1 & .3 & .3 & .3 \\
Diploma & 52 & 14.9 & 14.9 & 15.1 \\
Valid & university degree 59 & 16.9 & 16.9 & 79.4 \\
bachelor & 166 & 47.4 & 47.4 & 62.6 \\
Post grad & 72 & 20.6 & 20.6 & 100.0 \\
Total & 350 & 100.0 & 100.0 & \\
\hline
\end{tabular}

Based on the results in Table 4.3 regarding education, the highest percentage (47.4\%) of respondents have Bachelors degrees, followed by $20.6 \%$ with post graduate degrees, $16.9 \%$ who are university students, and $14.9 \%$ with Diplomas. 
4) Income

Table 9. Frequency distribution, percentage of income

\begin{tabular}{|c|c|c|c|c|}
\hline Monthly Income level & Frequency & y Percent & tt Valid Percent & t Cumulative Percen \\
\hline Less than $500 \mathrm{JD}$ & & 3.1 & 3.1 & 3.1 \\
\hline 500- 999 JD & 124 & 35.4 & 35.4 & 38.6 \\
\hline Valid 1000-1499 JD & 140 & 40.0 & 40.0 & 78.6 \\
\hline $1500-1999$ & 55 & 15.7 & 15.7 & 94.3 \\
\hline 2000 and above & 20 & 5.7 & 5.7 & 100.0 \\
\hline Total & 350 & 100.0 & 100.0 & \\
\hline
\end{tabular}

Based on the results in Table 4.4 which was related to the income variable, the highest percentage $(40 \%)$ of respondents earn between 1000-1499 JD, followed by 35.4\% who earn between 500-999 JD, followed by $15.7 \%$ who earn between 1500 to $1999 \mathrm{JD}$, followed by $5.7 \%$ who earn $2000 \mathrm{JD}$ or above, and finally $3.1 \%$ who earn less than $500 \mathrm{JD}$.

5) Frequency of using internet banking

Table 10. Frequency distribution, frequency of using internet banking per month

\begin{tabular}{cllll}
\hline frequency of using & \multicolumn{5}{l}{ Frequency Percent Valid Percent Cumulative Percent } \\
\hline Once a month & 98 & 28.0 & 28.0 & 28.0 \\
Twice a month & 88 & 25.1 & 25.1 & 53.1 \\
Three times & 70 & 20.0 & 20.0 & 73.1 \\
Valid & Four times a month 72 & 20.6 & 20.6 & 93.7 \\
More than 5 times & 22 & 6.3 & 6.3 & 100.0 \\
Total & 350 & 100.0 & 100.0 & \\
\hline
\end{tabular}

Most respondents reported using internet banking once a month (28\%) followed by those who use it twice a month $(25.1 \%)$.

\subsubsection{Multicollinearity Analysis}

Multicollinearity Analysis is considered an important test in multiple regression analysis. Multicollinearity is found when there is a strong correlation between two or more independent variables in the regression model (Field, 2004).

The collinearity exists when one of the independent variables has a perfect linear correlation with other variables. If two independent variables are perfectly correlated then this would lead to a biased regression model.

Multicollinearity can be measured by various statistical analysis. In this study the researcher based upon two analysis which are the Variance Inflation Factor (VIF) and the tolerance measure. According to Bowerman and O'Connell (1990) if the VIF is greater than 10, then there is a cause for concern. If the tolerance is below 0.1, then there is a serious problem.

Table 11. Collinearity statistics

\begin{tabular}{ll}
\hline Model Tolerance VIF & Collinearity Statistics \\
\hline Perceived ease of use & 2274.414 \\
Perceived usefulness & .2184 .584 \\
Compatibility & .1735 .786 \\
Trialability & .2774 .555 \\
Security & .2454 .088 \\
\hline
\end{tabular}

According to Table 11, the values of Tolerance range between .277 and .173 which is acceptable, as for the VIF, 
the values range between 4.088 and 5.786 which is also acceptable. This indicates that there is no collinearity within the data. This implies that there is no problem in the model with interchangeable Beta values between independent variables.

\subsubsection{Descriptive Analysis}

In this part the researcher will use descriptive analysis to answer the question of this study: "What are the factors affecting internet banking adoption among Jordanian clients?"

Table 12. Means, standard deviations, and levels applied for the variables of the study

\begin{tabular}{lllllll}
\hline Statistics & \multicolumn{1}{l}{} \\
\hline & $\begin{array}{l}\text { Internet } \\
\text { banking adoption }\end{array}$ & \multicolumn{1}{l}{ Perceived ease of use Perceived usefulness compatibility Trialability security } \\
& 3.9114 & 3.9865 & 3.9286 & 3.8352 & 3.9276 & 3.7733 \\
Mean & .55712 & .61869 & .58406 & .61071 & .62632 \\
\hline
\end{tabular}

Note. Descriptive analysis / Mean, Standard deviation for each variable: a) dependent variable (internet banking adoption).

As stated before, a five (5) Likert Scale ( $1=$ Strongly Disagree, $5=$ Strongly Agree) was used to measure all of the variables. Perceived ease of use was reported to have the highest mean score of 3.98, followed by Trialability $($ mean $=3.92)$, usefulness $($ mean $=3.92)$, compatibility $($ mean $=3.83)$, and security (mean $=3.77)$. Hence, it can be concluded that, all of the mean scores reported were more towards "agree" to "strongly agree" opinions, are in the upper level, and are considered high. Meanwhile, the standard deviation for all the variables under investigation ranged from 0.55 to 0.63 indicating that the answers are nearly normally distributed.

Table 13. Mean and standard deviation for the dependent variable (internet banking adoption)

\begin{tabular}{|c|c|c|c|}
\hline \multicolumn{4}{|l|}{ Statistics } \\
\hline & $\begin{array}{l}\text { I am highly convinced in using I } \\
\text { internet banking }\end{array}$ & $\begin{array}{l}\text { I am willing to use interne } \\
\text { services more frequently }\end{array}$ & $\begin{array}{l}\text { I will highly recommend my friends to adopt } \\
\text { internet banking services }\end{array}$ \\
\hline \multirow{2}{*}{$\begin{array}{l}\text { Valid } \\
\text { Missing }\end{array}$} & 350 & 350 & 350 \\
\hline & 0 & 0 & 0 \\
\hline \multicolumn{4}{|l|}{ Mean } \\
\hline $\begin{array}{l}\text { Std. } \\
\text { Deviation }\end{array}$ & 3.88 .682 & 3.86 .778 & 3.99 .734 \\
\hline
\end{tabular}

The means of the questions on internet banking adoption ranged between 3.86 and 3.99 with a standard deviation range between .68 and .78 . The highest mean resulted from question 3, indicating that the client would recommend the internet banking service to her/his friends, whereas the minimum mean of 3.8 resulted from questions no. 1 and 2 .

b) Perceived ease of use

Table 14. Mean and Standard deviation for the perceived ease of use

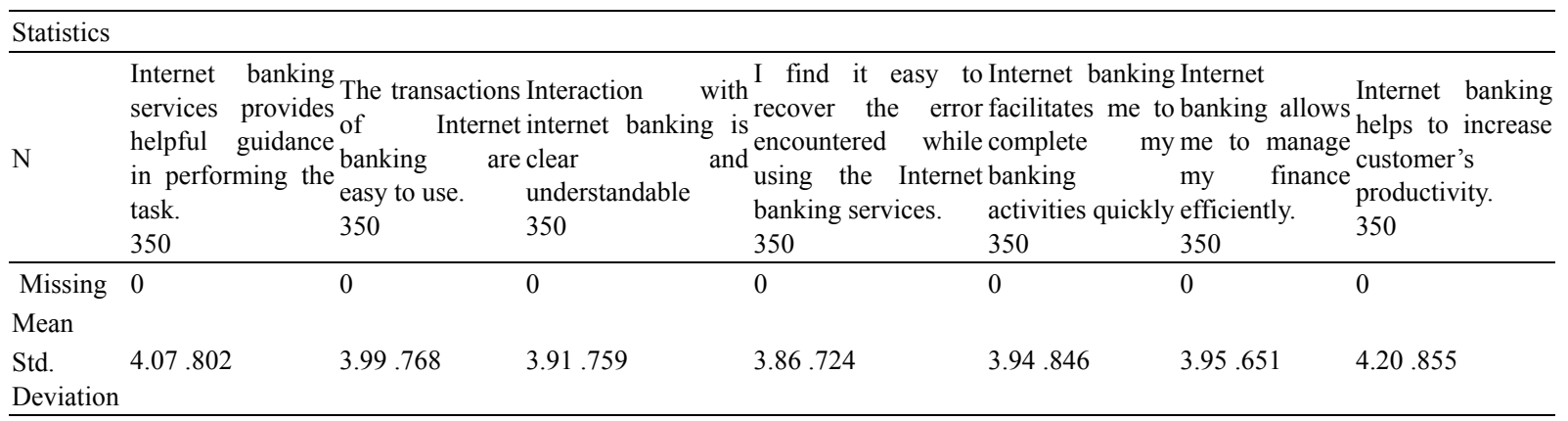


The means of the questions of perceived ease of use represented in table (4.8) were very close and ranged between 3.9 and 4.07 which is considered on the higher range, with a

standard deviation between .65 and .85 These results indicate that the internet banking service is easy to use, and will assist in building and enhancing the good image of internet banking adoption for the clients.

c) Perceived usefulness

Table 15. Mean and standard deviation for perceived usefulness

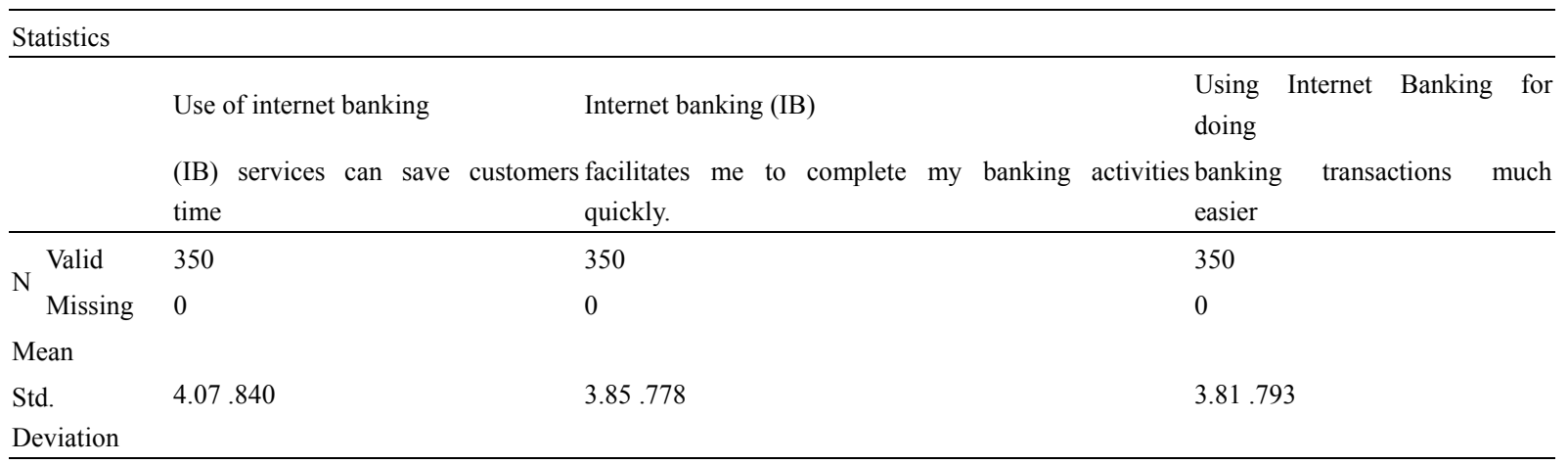

Perceived usefulness was reported to have the highest mean scores of 4.07 for the first question, followed by question no. 2 (mean $=3.85)$, and question no. 3 (mean $=3.81)$. Hence, it can be concluded that most of the mean scores for the perceived usefulness were more towards "agree" to "strongly agree" opinions, are in the upper level, and are considered high. This indicates that the consumer generally believes in the perceived usefulness and the promises of the internet banking services.

d) Compatibility

Table 16. Mean and standard deviation for internet banking compatibility

\begin{tabular}{|c|c|c|c|}
\hline \multicolumn{4}{|l|}{ Statistics 49} \\
\hline & $\begin{array}{l}\text { Online Banking i } \\
\text { with my lifestyle }\end{array}$ & $\begin{array}{l}\text { Using Online Banking fits } \mathrm{w} \\
\text { I like to manage my finances }\end{array}$ & $\begin{array}{l}\text { Using online Banking to conduct banking } \\
\text { transactions fits into my work profile }\end{array}$ \\
\hline \multirow{2}{*}{$\begin{array}{l}\text { Nalid } \\
\text { Missing }\end{array}$} & 350 & 350 & 350 \\
\hline & 0 & 0 & 0 \\
\hline \multicolumn{4}{|l|}{ Mean } \\
\hline $\begin{array}{l}\text { Std. } \\
\text { Deviation }\end{array}$ & 3.73 .753 & 3.95 .842 & 3.83 .802 \\
\hline
\end{tabular}

Compatibility was reported to have the lowest mean scores ranging between 3.73 and 3.83 , with the standard deviation ranging between .75 and .84 , but the results are still at the higher level. This indicates that Jordanian clients still do understand the service well enough for it to be compatible with their life style, and only a segment of those consumers believe that the information provided by the online banking website can be trustworthy.

e) Trialability

Table 17. Mean and standard deviation for trialability

\begin{tabular}{|c|c|c|c|}
\hline \multicolumn{4}{|c|}{ Statistics 50} \\
\hline & $\begin{array}{l}\text { I want to be able to use Internet } \\
\text { Banking on trial basis to see what it }{ }_{t} \\
\text { can do. }\end{array}$ & $\begin{array}{l}\text { It would not take much effort to } \\
\text { try using Internet banking service }\end{array}$ & $\begin{array}{l}\text { Internet banking access is triable and available } 24 / 7 \\
\text { using different hardware methods (Laptop, I pad, } \\
\text { Mobile) }\end{array}$ \\
\hline Valid & 350 & 350 & 350 \\
\hline${ }^{\mathrm{N}}$ Missing & 0 & 0 & 0 \\
\hline Mean & & & \\
\hline $\begin{array}{l}\text { Std. } \\
\text { Deviation }\end{array}$ & 3.82 .790 & 4.04 .816 & 3.93 .730 \\
\hline
\end{tabular}


The means of the questions of trialability ranged between 3.82 and 4.04. The highest mean resulted for questions no. 2 indicating that most clients stated that it would not take much effort to try using Internet banking services.

f) Security

Table 18. Mean and standard deviation for internet banking compatibility

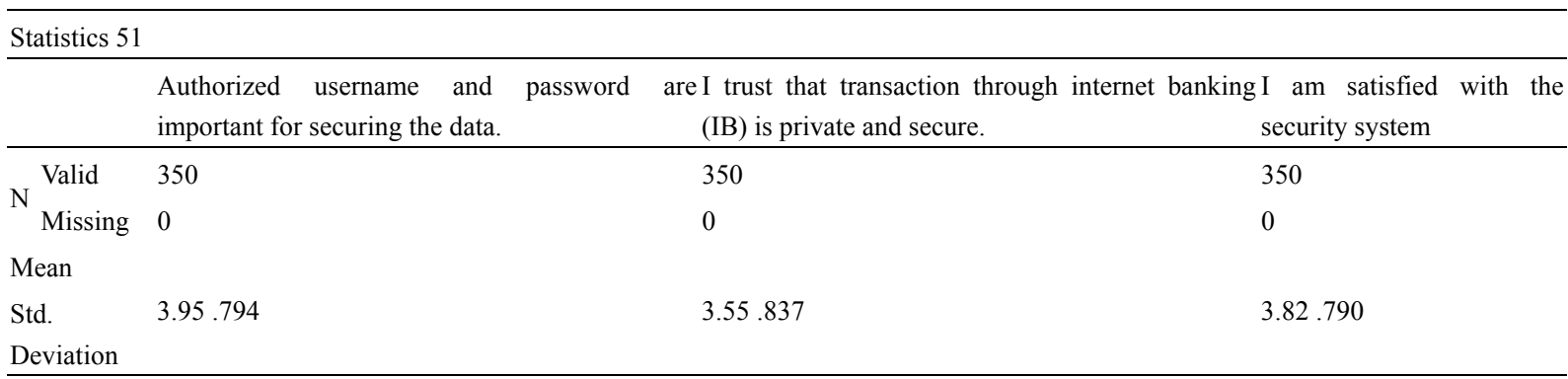

The means of the questions on security ranged between 3.55 and 3.95. The highest mean resulted from questions no. 1, indicating that most consumers stated that authorized username and password are important for securing data, while the lowest mean (3.55) resulted from question no. 2, indicating that although people are kind of satisfied with the system they do not really trust that a transaction through internet banking (IB) is private and secure.

\subsection{Testing Hypothesis}

The purpose of the hypotheses testing is to determine accurately if the null hypotheses (denoted by H0) can be rejected in order to support the alternate hypothesis (denoted by H1) (Sekaran \& Bougie, 2010). The probability value ( $\mathrm{p}$-value) obtained from the statistical hypothesis test is considered the decision rule for rejecting the null hypothesis (Creswell, 2003). If the p-value is greater than a predetermined level of significance ( $\alpha$-level), then the null hypothesis cannot be rejected and no support will be claimed for the alternative hypothesis. By contrast, if the p-value is less than or equal to than the $\alpha$-level, then the null hypothesis will be rejected and the alternative hypothesis will be supported.

Multiple Regression Analysis, Analysis of Variance (ANOVA) and One Way Analysis of Variance were used to test the research main hypotheses of the study.

Multiple regression analysis and analysis of variance were conducted in order to examine the effect of the independent variables (taken separately or taken together) on internet banking adoption and to test the first and second hypotheses of the study.

One Way Analysis of Variance was used to test the effect of the clients' demographics on internet banking adoption and to test the third hypothesis of the study. In addition, Tukey's post hock tests were used to find the difference in variance.

\subsubsection{Testing the First Main Hypothesis}

There is no significant relationship between the independent variables (Perceived usefulness, perceived ease of use, compatibility, trialability, security) taken together and internet banking adoption.

Table 19. Results of regression analysis for the effect of the independent variables upon internet banking adoption

\begin{tabular}{ll}
\hline Model Summary & \\
\hline Model & 1 \\
$\mathrm{R}$ & $.866^{\mathrm{a}}$ \\
R Square & .751 \\
Adjusted R Square & .747 \\
Std. Error of the Estimat & .29435 \\
\hline
\end{tabular}

Note. a. Predictors: (Constant), security, compatibility, usefulness, ease of use, trial. 
Table 20. Analysis of variance for the effect of the independent variables taken together upon internet banking adoption

\begin{tabular}{lllll}
\hline ANOVA $^{\mathrm{a}}$ & & & \\
\hline Model & Sum of Squares df & Mean Square F & Sig. & result \\
\hline \multicolumn{2}{l}{ Regression 89.783} & 5 & 17.957 & $207.252 .000^{\mathrm{b}}$ \\
1 Residual & 29.805 & 344.087 & \multicolumn{2}{c}{ Reject the null hypothesis } \\
Total & 119.588 & 349 & \\
\hline
\end{tabular}

Note. a. Dependent Variable: internet banking adoption; b. Predictors: (Constant), security, compatibility, usefulness, ease of use, Trialability.

The correlation coefficient $\mathrm{R}$ is a statistical technique that shows whether and how strongly pairs of variables are related to each other. Here the correlation coefficient $\mathrm{R}$ is equal to .866 , which means that there is a strong positive relationship between the independent variables taken together and the internet banking adoption.

The coefficient of determination $\left(\mathrm{R}^{2}\right)$ presents the percentage of the variation in the dependent variable explained by the regression model. Here in this study, $\mathrm{R}$ square $=.751$ which means that $75 \%$ of the changeability of internet banking adoption has been explained by the independent variables taken together.

Adjusted $\mathrm{R}$ square value of this study equals .747 , which is very close to $\mathrm{R}$ square value $=.751$, since adjusted $\mathrm{R}$ square values are always less than or equal to $\mathrm{R}$ square. It means that if the model has been fitted the whole population participated rather than those who responded in the study, there would be .004 (.747 -.751) less variance in the model outcome. Adjusted R square is generally considered to be more accurate goodness- of - fit measure than R square

Table 20 contains the analysis of variance (ANOVA) permits to statistically test the main null hypothesis. The sig. column in the table presents the statistical significance of the variable and it has been checked for value below approximately 0.05 levels. Hence, it can be concluded from the table that that the F-ratio for this data is 207.252 which is significant at the level of $\mathrm{p}<0.05$ (sig. =.000). Consequently, the researcher rejected the main null hypothesis and accepted the main alternative hypothesis, which means that there is a significant relationship between the independent variables (security, compatibility, usefulness, ease of use, trialability) taken together and internet banking adoption.

\subsubsection{Testing the Second Hypothesis}

H02 - "There is no significant relationship between the independent variables (perceived usefulness, perceived ease of use, compatibility, trialability, and security) taken separately and internet banking adoption"

Table 21. Coefficients

\begin{tabular}{|c|c|c|c|c|c|}
\hline \multicolumn{6}{|l|}{ Coefficients $^{\mathrm{a}}$} \\
\hline \multirow{2}{*}{ Model } & \multicolumn{3}{|c|}{ Unstandardized Coefficients Standardized Coefficients } & \multirow{2}{*}{$\mathrm{t}$} & \multirow{2}{*}{ Sig. } \\
\hline & $\mathrm{B}$ & Std. Error & Beta & & \\
\hline (Constant) & .220 & .117 & & 1.880 & .061 \\
\hline ease of use & .616 & .063 & .587 & 9.798 & .000 \\
\hline usefulness & .244 & .045 & .258 & 5.457 & .000 \\
\hline compatibility & .232 & .049 & .232 & 3.081 & .112 \\
\hline trial & -.001 & .058 & -.001 & -.016 & .987 \\
\hline security & .098 & .047 & .104 & 2.058 & .010 \\
\hline
\end{tabular}

Note. a. Dependent Variable: internet banking adoption.

$>$ The multiple regressions were also used to test the second hypothesis. Table 21 showed the estimation of Beta for each independent variable of this study. Beta measures the contribution of each variable to the model. Ease of use had the highest beta among all independent variables with a value of .616, followed by usefulness and compatibility that had close beta values of .244 and .232, whereas security had a lower beta of .098 .

$>$ Trialability variable had insignificant beta of .001 .

The first sub hypothesis: H02.1: There is no significant relationship between perceived usefulness and internet 
banking adoption.

Table 21 contains the analysis of coefficients showing the significance of perceived usefulness at the level of $p$ $<0.05$ (sig. =.000). Consequently, the researcher rejected the null hypothesis and accepted the alternative hypothesis, which means that there is a significant relationship between the perceived usefulness value and internet banking adoption.

The second sub hypothesis: H02.2: There is no significant relationship between perceived ease of use and internet banking adoption.

Table 21 contains the analysis of coefficients showing significance at the level of $p<0.05$ (sig. $=.000$ ) for perceived ease of use. Consequently, the researcher rejected the null hypothesis and accepted the alternative hypothesis which means that there is a significant relationship between the perceived ease of use and internet banking adoption

The third sub hypothesis: H02.3: There is no significant relationship between compatibility and internet banking adoption.

Table 21 contains the analysis of coefficients showing significance at the level of $p<0.05$ (sig. $=.002$ ). Consequently, the researcher rejected the null hypothesis and accepted the alternative hypothesis, which means that there is a significant relationship between compatibility and internet banking adoption.

The forth sub hypothesis: H02.4: There is no significant relationship between trialability and internet banking adoption. Table 21 contains the analysis of coefficients showing significance at level $p<0.05$ (sig. $=.987$ ) for the trialability factor. Consequently, the researcher accepts the null hypothesis and rejects the alternative hypothesis, which means that there's no significant relationship between trialability and internet banking adoption.

The fifth sub hypothesis: H02.5: There is no significant relationship between security and internet banking adoption.

Table 21 contains the analysis of coefficients showing significance at the level of $p<0.05$ (sig. $=.010$ ). Consequently, the researcher rejected the null hypothesis and accepted the alternative hypothesis, which means that there is a significant relationship between security and internet banking adoption.

\subsubsection{Testing the Third Hypothesis}

"H03 - There is no difference in internet banking adoption due to "the clients characteristics such as: "gender, age, educational level and income level" taken separately.

1). Gender

Table 22. Mean and standard deviation of internet banking adoption according to gender

\begin{tabular}{lll}
\hline \multicolumn{2}{l}{ Descriptive Statistics "Internet banking adoption" } \\
\hline Male & Female \\
\hline Mean & 4.1854 & 3.7035 \\
Std. Deviation & .26025 & .66984 \\
\hline
\end{tabular}

Table 23. One way analysis of variance for the differences in internet banking adoption according to gender

\begin{tabular}{|c|c|c|c|}
\hline internet banking adoptio & n Sum of Squares Df. & Mean Square F & Sig. Results \\
\hline Between Groups & 19.939 & 19.939 & 69.632 .000 \\
\hline Within Groups Total & 99.649119 .58834834 & 9.286 & Reject the null hypothesis \\
\hline
\end{tabular}

Results in Table 22 showed that males have a higher level of internet banking adoption than females with a mean of 4.185 and a standard deviation of 0.26 . Meanwhile, females have a lower level of internet banking adoption with a mean of 3.70 and a standard deviation of 0.66 . Results in Table 22 shows that values are significant below 0.05 , which means that there is a statistically significant difference in internet banking adoption according to gender. So the null hypothesis related to gender should be rejected and the alternative hypothesis that there is a direct relationship between gender and internet banking adoption should be accepted. 
2). Age

Table 24. Means and standard deviation of internet banking adoption according to age

\begin{tabular}{lll}
\hline internet banking adoption & Mean & Std. Deviation \\
\hline $18-24$ & 4.1333 & .28109 \\
$25-34$ & 4.0615 & .43473 \\
$35-44$ & 3.7944 & .69696 \\
$45-54$ & 3.9728 & .38392 \\
55 and above & 3.9583 & .11785 \\
\hline
\end{tabular}

Table 25. One way analysis of variance for the differences in internet banking adoption according to age

\begin{tabular}{|c|c|c|c|}
\hline internet banking adoptic & Sum of Squares df & Mean Square I & Sig. result \\
\hline Between Groups & 5.477 & 1.369 & 4.140 .003 \\
\hline Within Groups Total & 114.110119 .588345349 & .331 & Reject the null hypothesis \\
\hline
\end{tabular}

Table 24 shows the means and standard deviations of internet banking adoption according to the suggested age categories. Results showed that all categories have a high level of internet banking adoption; the highest level was found between ages 18 and 34 years old with a mean of 4.13 and 4.06, and the lowest satisfaction were for the category of 55 years and above with a mean of 3.95 .

Results in Table 25 showed that values are significant below 0.05 which means that there is a statistical relationship between internet banking adoption and age of the consumer, so the null hypothesis should be rejected, thus there is significant relationship between consumers' age and internet banking adoption.

Table 26 Tukey's post hock comparisons in internet banking adoption according to the age level multiple comparisons

\begin{tabular}{|c|c|c|c|c|}
\hline \multirow{2}{*}{$\begin{array}{l}\text { (J) Age Mean Difference (I-J) } \\
25-34.07184\end{array}$} & \multicolumn{2}{|c|}{ Std. Error Sig. } & \multicolumn{2}{|c|}{$\begin{array}{l}\text { 95\% Confidence Interval } \\
\text { Lower Bound Upper Boun }\end{array}$} \\
\hline & .19049 & .996 & -.4505 & .5942 \\
\hline 35- 44.33889 & .18685 & .367 & -.1735 & .8513 \\
\hline $45-54.16054$ & .19956 & .929 & -.3867 & .7078 \\
\hline 5.17500 & .27280 & .968 & -.5731 & .9231 \\
\hline $18-24-.07184$ & .19049 & .996 & -.5942 & .4505 \\
\hline $35-44.26704^{*}$ & .07105 & .002 & .0722 & .4619 \\
\hline 45-54.08870 & .09981 & .901 & -.1850 & .3624 \\
\hline 5.10316 & .21108 & .988 & -.4757 & .6820 \\
\hline $18-24-.33889$ & .18685 & .367 & -.8513 & .1735 \\
\hline $25-34-.26704^{*}$ & .07105 & .002 & -.4619 & -.0722 \\
\hline $45-54-.17834$ & .09267 & .306 & -.4325 & .0758 \\
\hline $5-.16389$ & .20780 & .934 & -.7337 & .4060 \\
\hline $18-24-.16054$ & .19956 & .929 & -.7078 & .3867 \\
\hline $25-34-.08870$ & .09981 & .901 & -.3624 & .1850 \\
\hline $35-44.17834$ & .09267 & .306 & -.0758 & .4325 \\
\hline 5.01446 & .21930 & 1.000 & -.5869 & .6158 \\
\hline $18-24-.17500$ & .27280 & .968 & -.9231 & .5731 \\
\hline $25-34-.10316$ & .21108 & .988 & -.6820 & .4757 \\
\hline $35-44.16389$ & .20780 & .934 & -.4060 & .7337 \\
\hline $45-54-.01446$ & .21930 & 1.000 & -.6158 & .5869 \\
\hline
\end{tabular}

Note. *. The mean difference is significant at the 0.05 level. 
Table 26 showed that the source of variation in internet banking adoption was between clients age 25-44 on one side and clients aged greater than 45 on the other side.

3). Educational Level

Table 27. Means and standard deviation of internet banking adoption according to educational level

\begin{tabular}{|c|c|c|}
\hline Educational Level & Mean & Std. Deviation \\
\hline High & 3.6667 & \\
\hline \multicolumn{3}{|c|}{ Diploma university deg 3.44234 .04621 .03684 .42625} \\
\hline bachelor & 3.9322 & .41421 \\
\hline Post grad Total & 3.92593 .9114 & 4.38036 .58537 \\
\hline
\end{tabular}

Table 28. One way analysis of variance for the differences in internet banking adoption according to educational level

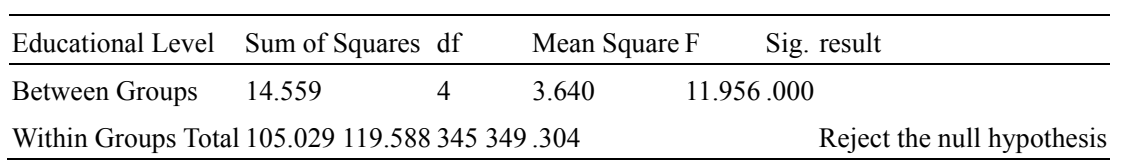

Table 27 shows the means of internet banking adoption according to education levels. Results show that all categories have a high level of internet banking adoption but university students and holders of bachelor and post graduate degrees had a higher mean than diploma holders.

Results in table 28 showed that values are significant below 0.05 , which means that there is a statistical difference in internet banking adoption according to education level. So, the null hypothesis related to education level should be rejected.

Table 29. Tukey's post hock comparisons in internet banking adoption according to educational level

\begin{tabular}{cllll}
\hline & \multicolumn{4}{c}{ Diploma University Students Bachelor Degree Post graduate } \\
\hline High School & -0.07 & $-.21^{*}$ & $-.18^{*}$ & $-.19^{*}$ \\
Diploma & & -0.14 & -0.11 & -0.13 \\
Internet banking adoption & & & 0.03 & 0.02 \\
& University Students & & & -0.02 \\
\hline & Bachelor Degree & & & \\
\hline
\end{tabular}

Table 29 shows that the source of variation in internet banking adoption is between the high school and diploma degree holders on one side and with the university students and bachelor and post graduate degree holders on the other side.

4). Income Level

Table 30. Means and standard deviation of internet banking adoption according to income level

\begin{tabular}{lll}
\hline internet banking adoption & Mean & Std. Deviation \\
\hline Less than 500 JD & 3.1818 & .22918 \\
500- 999 JD & 3.8145 & .78295 \\
$1000-1499$ JD & 3.9976 & .46198
\end{tabular}

1500-1999 2000 and above Total 3.8545 3.9167 3.9114.40957 .30349.58537

Table 31. One way analysis of variance for the differences in internet banking adoption according to income level

\begin{tabular}{|c|c|c|c|c|}
\hline \multicolumn{3}{|c|}{ internet banking adoption Sum of Squares df } & Mean Square F & Sig. \\
\hline Between Groups & 3.187 & 4 & .797 & 2.362 .044 \\
\hline Within Groups Total & 116.400119 .588 & 8345 & 9.337 & \\
\hline
\end{tabular}


Table 30 shows the means of internet banking adoption according to the suggested income levels. Results show that all categories have a high level of internet banking adoption.

Results in table 31 showed that values are significant below 0.05 , which means that there is a statistically significant difference in internet banking adoption according to income level. So the null hypothesis related to education level should be rejected and it should be accepted that there is a direct relationship between education level and internet banking adoption.

Table 32. Tukey's post hock comparisons in the internet banking adoption according to income level

\begin{tabular}{cllll}
\hline \multicolumn{4}{c}{ 500- 999 JD 1000-1499 JD 1500- 1999 JD 2000 JD and above } \\
\hline Less than 500 JD -0.12 & $-.44^{*}$ & $-.28^{*}$ & -0.17 \\
Internet banking adoption 500-999 JD & -0.32 & -0.17 & -0.06 \\
& $1000-1499$ JD & & 0.16 & 0.26 \\
1500-1999 JD & & & 0.11 \\
\hline
\end{tabular}

According to Table 31 the source of difference in internet banking adoption is between the clients earning a lower level of income (less than $1000 \mathrm{JDs}$ ) on one side and the consumers earning more than $1000 \mathrm{JDS}$ on the other side.

\section{Conclusion}

This section presents a comprehensive description of the results and discussions of this study. Analysis of the results found in the previous section provided findings which will be used to answer the research question, "What are the factors affecting internet banking adoption among Jordanian clients?"

The findings and their implications will be discussed in detail, using previous research findings for comparison.

\subsection{Results and Discussion}

The study observed the factors affecting internet banking adoption among banks' clients in Jordan. This study was able to conceptualize how compatibility, perceived usefulness, trialability, perceived ease of use and security affect internet banking adoption. In this study a five (5) Likert Scale was used to measure all of the variables. The means of those variables ranged between 3.91 and 3.77 and the standard deviation ranged between .55 and .62 basing on Table above; so it can be concluded that all of the mean scores reported were more towards "agree" to "strongly agree" opinions, indicating that in general, all of those variables are viewed as important by the respondents.

The perception of ease of use had the highest mean of 3.98 and standard deviation of .55 based on Table above. This points out that the sample is aware of the significance of perceived ease of use and this was supported by the literature (Liao, Shao, Wang, \& Chen, 1999). Hence it should be realized that perceived ease of use is an important factor, which means that clients need easier internet banking.

Perceived usefulness followed perceived ease of use with a close mean of 3.9114, which also indicates that the sample is aware of the importance of perceived usefulness and this was supported by the literature (Liao, Shao, Wang, \& Chen, 1999). Hence resources should be invested to attempt to increase perceived usefulness.

In the study, the results showed the presence of a statistically significant positive relationship between the independent factors taken together or taken separately. The model has an integrative structure because it tries to anticipate the effect of gathering all the independent factors together and tries to identify if a relationship exists between them and internet banking adoption. According to the multiple regression analysis and the analysis of variance (ANOVA), the first null hypothesis was rejected and the alternative hypothesis was accepted and a significant relationship was found between the independent variables (compatibility, perceived usefulness, trialability perceived ease of use and security) taken together and internet banking adoption. Synergistic relation between these factors should be secured in order to ensure their effect on internet banking adoption.

Additionally, Table 20 shows that there is a statistical significant positive relationship between perceived ease of use and internet banking adoption. This result is corresponding to the findings of Eriksson, Kerem, and Nillson (2004) who supported the positive relationship between perceived ease of use and internet banking adoption.

This study concluded a positive relationship between compatibility and internet banking adoption since Beta between compatibility and internet banking adoption was found to be .232 according to Table 20 . This finding is 
consistent with what has been demonstrated in the previous relevant studies, including Tan, Teo, (2000) and Black, Lockett, Winklohofer, and Ennew (2001), indicating that when clients believe in the compatibility of internet banking adoption, they are more likely to be convinced to adopt online banking and use the services provided more frequently.

In addition to the above this study concluded a positive relationship between security and internet banking adoption since Beta between security and internet banking adoption was found to be .098 according to Table 20 . This shows a positive relationship between them. This finding is consistent with what has been demonstrated in the previous relevant studies. According to Tan, Teo, (2000) and Black, Lockett, Winklohofer, and Ennew (2001) because consumers perceive lower risk in performing their daily banking transactions online in comparison to performing them in the traditional ways (visiting the physical branch), since there is no chance of human mistakes, they are willing to adopt internet online banking services.

Finally, this study developed a deeper understanding of clients' internet banking trialability of online banking provided services. According to Table 4.14, which demonstrates the results of regression analysis for the trialability upon internet banking adoption, Beta had the lowest level and was equal to -.001 which indicates that trialability and internet banking adoption are negatively related.

The study surveyed a sample of consumers who play roles in internet banking services adoption decision, the majority of respondents were males with 56.9 percent while the females' percentage was 43.1 percent. The age group was consisted of 80.8 percent of respondents between 25 and 44 years old and 16.3 percent were 45 years and above. The allocation of the sampled results according to the education level of the respondents indicated that 20.6 percent have a postgraduate degree while 16.9 percent were university students and 16.9 percent have bachelor degrees. The sampled respondents' monthly income showed that 35.4 percent of the respondents earn less than 1000 JOD Jordanian Dinars per month, 40 percent earn between 1000 and 1499 JOD Jordanian Dinars per month, while only 15.7 percent earn monthly incomes between 1500-1999 Jordanian Dinars. 5.7 percent of the population sample earns 2000 JOD Jordanian Dinars and above per month.

As for analysis of the respondents' demographic characteristics (age, gender, education and income) and their effect on internet banking adoption, the results revealed the following:

In the study conducted on gender and whether it has an effect on internet banking adoption, a positive relationship was found between gender and internet banking adoption and males were found to have a higher tendency to adopt internet banking than females. This result is supported by Sara Naimi (2008).

Age was found to have an effect on internet banking adoption and the alternative hypothesis was accepted, so there is a statistical difference in internet banking adoption according to the age of the consumer. In Table 4.17 the results showed that all age categories have a high level of internet banking adoption, but the highest level was found among the youngest, aged between 18 and 34 years old with a mean of 4.13 and 4.06. The lowest were for the category of 55 years and above with a mean of 3.91. Researchers in the literature agreed that young people are likely to be more sensitive to internet banking adoption (Wngwanit-Chackron, 2002).

The researcher carried out the analysis for the education levels. The results shown in Table 26 and 27 indicate that statistically there is a difference in internet banking adoption according to education levels. Results show that all categories have a high level of internet banking adoption, but the highest levels were found among university students and holders of bachelor and post graduate degrees. This finding supports previous literature, which indicates that consumers who more frequently adopt internet banking are more highly educated people (Wngwanit-Chackron, 2002).

The income level and whether it has an effect on internet banking adoption was investigated by the researcher. The results in Table 28 reveal that consumers who have higher income levels are more likely to adopt internet banking services. Also it shows that all categories have a high level of internet banking adoption but the highest level was found among the clients with an income level of 1000 JDs per month or above. This finding is supported by many previous studies that pointed out that consumers with high income were found to adopt internet banking services (Wngwanit-Chackron, 2002).

The following Figure 2 shows the modified theoretical framework of the research according to the values of Beta. The independent variables are listed in a descending manner to show their significance upon internet banking adoption bearing in mind that the trialability variable was omitted since it has no effect on internet banking adoption. Moreover, the $\mathrm{R}$ value shows the strong positive relationship between the independent variables taken together and the internet banking adoption $\mathrm{R}^{2} 0.68$. 


\subsection{Recommendations and Implications}

The structural model of the study added a new concept by trying to analyze the effect of all the independent factors together on internet banking adoption. The correlation between them was reasonably high and positive $\mathrm{R}=.866$. In order to improve internet banking adoption, banks should combine the concepts of perceived ease of use, compatibility, and security into the online banking services concepts in the stage of marketing planning and ensure proper synergy between these variables in order to increase the level of internet banking adoption.

Among the factors affecting internet banking adoption, ease of use value had a correlation coefficient of .587 and this implies that the consumer perceptions of value plays a key role in affecting the internet banking adoption. So, according to the findings, banks should enhance their website ease of use and they may be required to invest in building the website infrastructure to ensure that the services will be user friendly in its design, functions and usage in order to influence the decision of clients towards the adoption of those services. Moreover, since the clients evaluate the product in terms of its easiness; then this may be applied by banks to evaluate the website performance for their provided banking services and utilize this approach for gaining competitive advantage over the traditional ways of conducting banking transactions.

Internet banking security in this study had a mean of 3.77, which indicates that the sample viewed this factor as major. A useful starting point for marketers is to develop strategies for raising internet banking adoption by being transparent in online banking claims, and by helping potential clients to develop sufficient trust which will lead to building a long-term relationship and increase their willingness to frequently use online banking provided services.

Internet banking usefulness have a positive effect on internet banking adoption and the banks' clients believed that use of internet banking (IB) services can save customers time and facilitates to complete the banking activities and transactions quickly in an easier way.

Compatibility was found to have a beta of .232 among the independent variables, and the banks' clients believe that it is well-matched with their lifestyle and fits with the way they like to manage their finances and works well with their work profile. This was proven by Internet Banking user acceptance: Evidence from Greece et al., (2009).

Looking into the demographic results, marketers and banks can improve their advertising activities. The findings of the study concluded that the demographic variables had an effect on internet banking adoption.

Demographic factors have been found to be related to the adoption of various banking channels, particularly internet banking (e.g., Karjaluoto et al., 2002; Sathye, 1999; Al-Ashban \& Burney, 2001). As showed by this research the number of males that use internet banking were higher than the number of females that use it (e.g. Akinci et al., 2004). One of this research findings showed that younger or older consumers are less likely to use internet banking than middle-aged consumers. Moreover, younger, wealthier and more educated customers are more likely to use internet banking, which is also supported by (e.g., Karjaluoto et al., 2002; Mattila et al., 2003; Sathye, 1999). In Jordan, as was discussed earlier, younger consumers more than older consumers like to use Internet banking (Filotto et al., 1997).

The findings of the study are particularly important from managerial and marketing perspectives. More than purely building marketing strategies and campaigns focused on general banking concerns, it is important from the banks clients' perspective to focus on the internet banking features, advantages and benefits.

\section{References}

Adams D. A., Nelson, R. R., \& Todd, P. A. (1992). Perceived Usefulness, Ease of Use, and Usage of Information Technology: A Replication. MIS Quarterly, 16(2), 227-247. http://dx.doi.org/10.2307/249577

Alagheband, P. (2006). Adoption of electronic banking services by Iranian customers. Master Thesis, Lulea University of Technology. $\quad$ Retrieved from http://epubl.luth.se/1653-0187/2006/49/LTU-PB-EX-0649-SE.pdf

Athanasios, G. P., \& Tim, H., \& Don, W. (2012). Internet shopping and Internet banking in sequence. Working Papers, Department of Accounting, Economics and Finance, Bristol Business School, University of the West of England, Bristol.

Agarwal, R., \& Prasad, J. (1998). A conceptual and operational definition of personal innovativeness in the domain of information technology. Information Systems Research, 9(2), 204-215. http://dx.doi.org/10.1287/isre.9.2.204

Al Sukkar, A., \& Hasan, H. (2005). Toward a model for the acceptance of internet banking in developing 
countries. Information Technology for Development, 11(4), 381-398. http://dx.doi.org/10.1002/itdj.20026

Akinci, S., Aksoy, S., \& Atılgan, E. (2004). Adoption of internet banking among sophisticated consumer segments in an advanced developing country. International Journal of Bank Marketing, 22(3), 212-232. http://dx.doi.org/10.1108/02652320410530322

Al-Qeisi, K. (2009). Analyzing the use of UTAUT model in explaining an online behavior: internet banking adoption. Unpublished doctoral dissertation.UK, Brunel University, Phd, theses.

Awamleh, R., Evans, J., \& Mahate, A. (2003). Internet banking in emergency markets: the case of Jordan - a note. Journal of Internet Banking and Commerce, 8(1).

Akinci, S., Aksoy, S., \& Atilgan, E. (2004). Adoption of internet banking among sophisticated consumer segments in an advanced developing country. International Journal of Bank Marketing, 22(3), 212-232. http://dx.doi.org/10.1108/02652320410530322

Black, N. J., Lockett, A., Winklhofer, H., \& Ennew, C. (2001). The adoption of internet financial services: a qualitative study. International Journal of Retail \& Distribution Management, 29(8), 390-398. http://dx.doi.org/10.1108/09590550110397033

Black, N. J., Lockett, A., Ennew, C., Winklhofer, H., \& McKechnie, S. (2002). Modeling customer choice of distribution channels: an illustration from financial services. International Journal of Bank Marketing, 20(4), 161-173. http://dx.doi.org/10.1108/02652320210432945

Bagozzi, R. P. (2007). The Legacy of the Technology Acceptance Model and a Proposal for a Paradigm Shift. Journal of the Association for Information Systems, 8(4), 243-254.

Bowerman, L., \& O’Connell, T. (1990). Linear statistical models: an applied approach (2nd ed.). Belmont, CA: Duxbury.

Cooper, R. G. (1997). Examining Some Myths About New Product Winners. In Katz, R. (Ed.), The Human Side of Managing Technological Innovation (pp. 550-560). Oxford.

Chong, A., Ooi, K. B., Lin, B., Tan, B. I. (2010). Online banking adoption: an empirical analysis. International Journal of Bank Marketing, 28(4), 267-287. http://dx.doi.org/10.1108/02652321011054963

Churchill, G. A. (1979). A paradigm for developing better measures of marketing constructs. Journal of Marketing Research, 16, 64-73. http://dx.doi.org/10.2307/3150876

Collis, J., \& Hussey, R. (2003). Business Research: A Practical Guide for Undergraduate and Postgraduate Students. Palgrave Macmillan, Houndmills, Basingstoke, Hampshire.

Chung, W., \& Paynter, J. (2002). An evaluation of internet banking in New Zealand. Proceedings of the 35th Hawaii International Conference on System Sciences. http://dx.doi.org/10.1109/HICSS.2002.994178

Churchill, G. A. (1979). A paradigm for developing better measures of marketing constructs. Journal of Marketing Research, 16. http://dx.doi.org/10.2307/3150876

Chi, S. Y., Grant, K., \& Edgar, D. (2007). Factors affecting the adoption of internet banking in Hong Kong-implications for the banking sector. International Journal of Information Management, 27, 336-351. http://dx.doi.org/10.1016/j.ijinfomgt.2007.03.002

Chisnall, P. M. (1997). Marketing Research. McGraw-Hill Publishing Company.

Daniel, E. (1999). Provision of Electronic Banking in the UK and the Republic of Ireland. The International Journal of Bank Marketing, 17(2). http://dx.doi.org/10.1108/02652329910258934

Dimitrios, M., Charalampos, T., \& Chrisostomos, G. (2009). Internet Banking user acceptance: Evidence from Greece and Bulgaria. 5th HSSS Conference, Democritus University of Thrace.

Dover, P. A. (1988). The Effect of Technology Selection on Consumer Adoption of the In-home Computerized Banking.

Davis, F. D. (1986). A Technology Acceptance Model for Empirically Testing New End-User Information Systems: Theory and Results. doctoral dissertation, MIT Sloan School of Management, Cambridge.

Davis, F. (1989). Perceived usefulness, perceived ease of use, and user acceptance of information technology. MIS Quarterly, 13(3), 318-339. http://dx.doi.org/10.2307/249008

Davis, F., Bagozzi, R., \& Warshaw, P. (1992). Extrinsic and intrinsic motivation to use computers in the workplace. Journal of Applied Social Psychology, 22, 1111-1132. 
http://dx.doi.org/10.1111/j.1559-1816.1992.tb00945.x

Davis, F. D., \& Venkatesh, V. (2003). Toward Preprototype User Acceptance Testing of New Information Systems: Implications for Software Project Management. IEEE Transactions on Engineering Management, 51(1), 31-46. http://dx.doi.org/10.1109/TEM.2003.822468

Eriksson, K., Kerem, K., \& Nilsson, D. (2005). Customer acceptance of Internet banking in Estonia. International Journal of Bank Marketing, 23(2), 200-216. http://dx.doi.org/10.1108/02652320510584412

Fink, L. D. (2003). Creating Significant learning Experiences: An Integrated Approach to Designing College Courses. Jossey-Bass Publishers, San Francisco.

Fishbein, M., \& Ajzen, I. (1981). Attitudes and Voting Behaviour: An Application of the Theory of Reasoned Action. Progress in Applied Social Psychology, 1, 253-313.

Field, A. (2004). Discovering statistics using SPSS. Advanced techniques for the beginner (2nd ed.). London: Sage.

Gardiner, P., \& Rothwell, R. (1985). Tough Customers: Good Designs. Design Studies, 6(1), 7-17. http://dx.doi.org/10.1016/0142-694X(85)90036-5

Gurn, B. K., Shanmngam, B., Alam, N., \& Perera, C. (2003). An evaluation of internet banking sites in Islamic countries. The Journal of Internet Banking and Commerce, 8(2).

Gounaris, S., \& Koritos, C. (2008) Investigating the drivers of internet banking adoption decision. International Journal of Bank Marketing, 26(5). http://dx.doi.org/10.1108/02652320810894370

Hsiao, C. H., \& Hung, Y. C. (2004). The study of behavior intention to accept mobile commerce in technology acceptance model. Unpublished master thesis, Tatung University, Taiwan.

Hernandez, J. M., \& Mazzon J. (2006). Adoption of Internet Banking: Proposition and implementation of an integrated methodology approach. International Journal of Bank Marketing, 25(2), 72-88. http://dx.doi.org/10.1108/02652320710728410

Henderson, R., \& Divett, M. J. (2003). Perceived usefulness, ease of use and electronic supermarket use. International Journal of Human-Computer Studies, 59, 383-395. http://dx.doi.org/10.1016/S1071-5819(03)00079-X

Howcroft, D. (2001). After the gold-rush: deconstructing the myths of the dot.com market. Journal of Information Technology, 16, 195-204. http://dx.doi.org/10.1080/02683960110100418

Howcroft, B., Hamilton, R., \& Hewer, P. (2002). Consumer attitude and the usage and adoption of home-based banking in the United Kingdom. The International Journal of Bank Marketing, 20(3), 111-121. http://dx.doi.org/10.1108/02652320210424205

Hung, S. Y., \& Chang, C. M. (2005). User acceptance of WAP services: Test of competing theories. Computer Standards \& Interfaces, 27, 359-370. http://dx.doi.org/10.1016/j.csi.2004.10.004

Khalfan, A. M., \& Alshawaf, A. (2004). Adoption and Implementation Problems of EBanking: A Study of The Managerial Perspective of The Banking Industry in Oman. Journal of Global Information Technology Management, 7(1), 47-64. http://dx.doi.org/10.1080/1097198X.2004.10856366

Keeler, D. (2007). Global finance names the world best internet banks in the Middle East/Africa 2007. Retrieved from http//www.gfmag.com/c_aw/0509-01.php

Karjalouto, H., Mattila, M, \& Pento, T. (2002). Factors underlying attitude formation toward online banking in Finland. International Journal of Bank Marketing, 20(6), 261-272. http://dx.doi.org/10.1108/02652320210446724

Kolodinsky, Jane, M., Hogarth, Jeanne, M., \& Hilgert, M. A. (2004). The adoption of electronic banking technologies by US companies. International Journal of Bank Marketing, 22(4), 238-259. http://dx.doi.org/10.1108/02652320410542536

Lederer, A. L., Maupin, D. J., Sena, M. P., \& Zhuang, Y. (2000). The technology acceptance model and the World Wide Web. Decision Support System, 29(3), 269-282. http://dx.doi.org/10.1016/S0167-9236(00)00076-2

Lukas, B., \& Hair, J. F. (2003). Marketing Research. Sydney, Australia, McGraw Hill Australia.

Liao, S., Shao, Y., Wang, H., \& Chen, A. (1999). The adoption of virtual banking: An empirical study. 


International Journal of Information $\quad$ Management, $\quad 19, \quad 63-74$.
http://dx.doi.org/10.1016/S0268-4012(98)00047-4

Mathieson, K. (1991). Predicting user intentions: Comparing the technology acceptance model with the theory of planned behavior. Information Systems Research, 2(3), 173-191. http://dx.doi.org/10.1287/isre.2.3.173

Mattila et al. (2003). Internet Banking Adoption among Mature Consumers: early Majority or Laggard. The Journal of Services Marketing, 17(4/5). http://dx.doi.org/10.1108/08876040310486294

McCoy, S., Galletta, D. F., \& King, W. R. (2006). Applying TAM across cultures: the need for caution. European Journal of Information Systems, 16, 81-90. http://dx.doi.org/10.1057/palgrave.ejis.3000659

Milind, S. (1999). Adoption of Internet banking by Australian consumers: an empirical investigation.

Moore, G. C., \& Benbasat, I. (1991). Development of an instrument to measure the perceptions of adopting an information technology innovation. Information Systems Research, 2(3), 192-222. http://dx.doi.org/10.1287/isre.2.3.192

O'Connell, B. (1996). Australian Banking on the Internet- Fact or Fiction? The Australian Banker, (December), 212-214.

Ostlund, L. E. (1974). Perceived innovation attributes as predictors of innovativeness. Journal of Consumer Research, 1, 23-29. http://dx.doi.org/10.1086/208587

Pikkarainen, T., Pikkarainen, K., Karjaluoto, H., \& Pahnila, S. (2004). Consumer acceptance of online banking extension of the TAM. Journal of Internet Research, 14(3), 224-235. http://dx.doi.org/10.1108/10662240410542652

Parasuraman, A., \& Grewal, D. (2000). The impact of technology on the quality- value-loyalty chain: A research agenda. Journal of the Academy of Marketing Science, 28(1), 168-174. http://dx.doi.org/10.1177/0092070300281015

Rudi, H., Paul, N., Pauline, M. (2001). Factors Affecting the Adoption of Internet Banking in South Africa: a Comparative Study. Information Systems Honours.

Rogers, E. (1983). Diffusion of Innovations (3rd ed.). New York: Free Press.

Rogers, E. M. (1995). The diffusion of innovations (4th ed.). New York: Free Press.

Rogers, E. M., \& Shoemaker, F. F. (1971). Communication of Innovations: A Cross-cultural Approach (2nd ed.). New York, NY.: Free Press.

Rotchanakitumnuai, S., \& Speece, M. (2003). Barriers to Internet banking adoption: A qualitative study among corporate customers in Thailand. International Journal of Bank Marketing, 21(6), 312-323. http://dx.doi.org/10.1108/02652320310498465

Sara, N. B. (2008). Factors influencing the adoption of internet banking (Master thesis).

Sciglimpaglia, D., \& Ely, D. (2002). Internet Banking: A Customer-Centric Perspective. In the proceedings of the 35th HICSS. IEEE Computer Society.

Sung, S. K., \& Naresh, K. M. (2005). Predicting System Usage from Intention and Past Use. Scale Issues in the Predictors, 36(1), 187-196.

Syed, A. R., \& Nida, H. (2011). Factors affecting internet banking adoption among internal and external customers: a case of Pakistan. Munich Personal RePEc Archive.

Scarbrough, H., \& Corbett, J. M. (1992). Technology and Organization Power, Meaning and Design. International Journal of Bank Marketing, 2, 31-37.

Sekaran, U. (2008). Research methods for business (4th ed.). Hoboken, NJ: John Wiley \& Sons.

Siam, A. (2006). Role of electronic banking services on the profits of Jordanian banks. American Journal of Applied Science, 3(9), 1999-2004. http://dx.doi.org/10.3844/ajassp.2006.1999.2004

Sekaran, U., \& Bougie, R. (2010). Research methods for business: A skill building approaches (5th ed.). Chichester: John Willey \& Sons Ltd.

Saunders et al. (2007). Research methods for business students. England, Prentice hall.

Stewart, K. (1999). Transference as Means of Building Trust in World Wide Web Sites. Proceedings of the 20th. ICIS, Charlotte, North Carolina. 
Tan, M., \& Teo, T. (2000). Factors Influencing the Adoption of Internet Banking. Journal of the Association for Information Systems, 1(5), 1-44.

Taylor, S., \& Todd, P. (1995). Decomposition and crossover effects in the theory of planned behaviour: A study of consumer adoption intentions. International Journal of Research in Marketing, 12, 137-155. http://dx.doi.org/10.1016/0167-8116(94)00019-K

Tan, M., \& Teo, T. (2000). Factors Influencing the Adoption of Internet Banking. Journal of the Association for Information Systems, 1(5), 1-44.

Teo, T. S. H., \& Pok, S. H. (2003). Adoption of WAP-enabled mobile phones among Internet users. Omega, 31, 483-498. http://dx.doi.org/10.1016/j.omega.2003.08.005

Tornatzky, L., \& Klein, K. (1982). Innovation characteristics and innovation adoption implementation: A meta-analysis of findings. IEEE Transactions on Engineering Management, 29(1), 28-45. http://dx.doi.org/10.1109/TEM.1982.6447463

Wu, I. L., \& Chen, J. L. (2004). An extension of Trust and TAM model with TPB in the initial adoption of on-line tax: An empirical study. International Journal of Human-Computer Studies, 62, 784-808. http://dx.doi.org/10.1016/j.ijhcs.2005.03.003

Zeithaml, V. A., Parasuraman, A., \& Malhotra, A. (2002a). Service quality delivery through web sites: a critical review of extant knowledge. Journal of the Academy of Marketing Science, 30(4), 362-376. http://dx.doi.org/10.1177/009207002236911

Trajhova, N. (2005). Global Finance names the world best internet bank in Middle East and Africa for 2005 online.

Wang, Y. S., Wang, Y. M., Lin, H. H., \& Tang, T. I. (2003). Determinants of user acceptance of Internet banking: an empirical study. International Journal of Service Industry Management, 14(5), 501-519. http://dx.doi.org/10.1108/09564230310500192

\section{Copyrights}

Copyright for this article is retained by the author(s), with first publication rights granted to the journal.

This is an open-access article distributed under the terms and conditions of the Creative Commons Attribution license (http://creativecommons.org/licenses/by/3.0/). 